Prepared in cooperation with the Arkansas Natural Resources Commission

\title{
Enhancements to the Mississippi Embayment Regional Aquifer Study (MERAS) Groundwater-Flow Model and Simulations of Sustainable Water-Level Scenarios
}
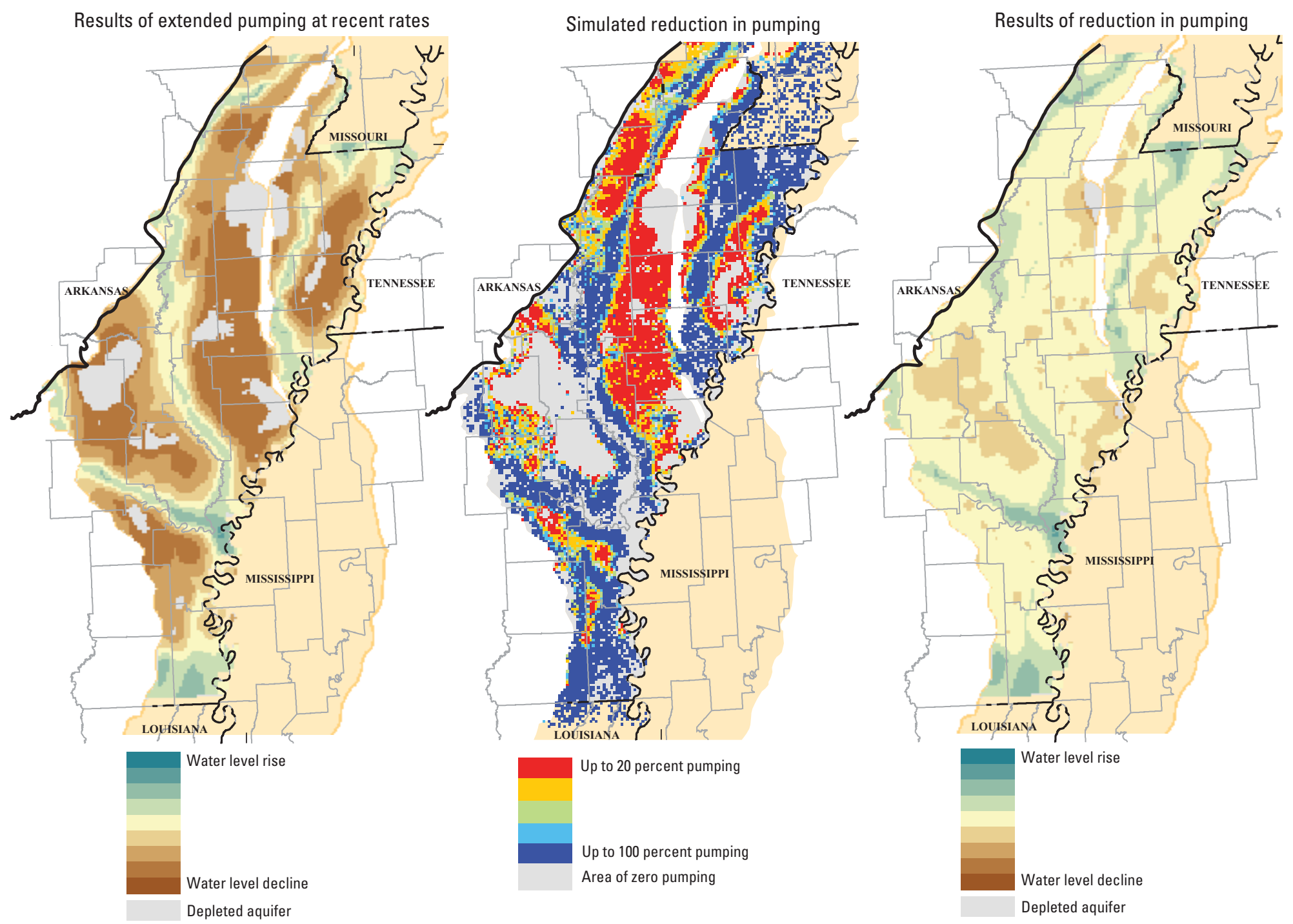

Scientific Investigations Report 2013-5161 



\section{Enhancements to the Mississippi Embayment Regional Aquifer Study (MERAS) Groundwater-Flow Model and Simulations of Sustainable Water-Level Scenarios}

By Brian R. Clark, Drew A. Westerman, and D. Todd Fugitt

Prepared in cooperation with the Arkansas Natural Resources Commission

Scientific Investigations Report 2013-5161 


\section{U.S. Department of the Interior \\ SALLY JEWELL, Secretary}

\section{U.S. Geological Survey \\ Suzette M. Kimball, Acting Director}

\section{U.S. Geological Survey, Reston, Virginia: 2013}

For more information on the USGS — the Federal source for science about the Earth, its natural and living resources, natural hazards, and the environment, visit http://www.usgs.gov or call 1-888-ASK-USGS.

For an overview of USGS information products, including maps, imagery, and publications, visit http://www.usgs.gov/pubprod

To order this and other USGS information products, visit http://store.usgs.gov

Any use of trade, firm, or product names is for descriptive purposes only and does not imply endorsement by the U.S. Government.

Although this information product, for the most part, is in the public domain, it also may contain copyrighted materials as noted in the text. Permission to reproduce copyrighted items must be secured from the copyright owner.

Suggested citation:

Clark, B.R., Westerman, D.A., and Fugitt, D.T., 2013, Enhancements to the Mississippi Embayment Regional Aquifer Study (MERAS) groundwater-flow model and simulations of sustainable water-level scenarios: U.S. Geological Survey Scientific Investigations Report 2013-5161, 29 p., http://pubs.usgs.gov/sir/2013/5161/. 


\section{Contents}

Abstract
Introduction
Methods
Evaluation of Model Enhancements
Comparison of Simulated and Observed Values
Simulated and Observed Hydrographs
Scenario Development
Simulations of Sustainable Water-Level Scenarios
Summary
References Cited

\section{Figures}

1. Map showing location of the Mississippi Embayment Regional Aquifer Study model area, with the primary focus of improvement within the State boundary of Arkansas

2. Maps showing pilot-point locations and values of $(A)$ hydraulic conductivity and $(B)$ specific storage used to represent the alluvial (and other surficial) aquifer ...

3. Maps showing pilot-point locations and values of $(A)$ hydraulic conductivity and $(B)$ specific storage used to represent the Sparta aquifer

4. Map showing pilot-point locations and values of vertical anisotropy used to represent the Vicksburg-Jackson confining unit 10

5. Map showing pilot-point locations and values of recharge multipliers .11

6. Graph showing comparison of root mean square error of the Mississippi River Valley alluvial aquifer between the Mississippi Embayment Regional Aquifer Study (MERAS) model versions 1.1 and 2.0

7. Graphs showing simulated and observed hydrographs of hydraulic head in selected wells

8. Graphs showing comparison of hydrographs for simulations using total pumping and a 50-percent reduction in pumping

9. Maps showing difference between simulated hydraulic head and the desired drawdown constraint of the $(A)$ alluvial aquifer and $(B)$ Sparta aquifer for scenario 1.

10. Map showing difference between simulated hydraulic head and half of the saturated thickness of the alluvial aquifer for scenario 2

11. Map showing percentage of desired pumping for scenario 2

12. Graph showing comparison of pumping rates in the alluvial and Sparta aquifers within the previously optimized areas among each scenario

13. Maps showing difference between altitudes of water level and half of the saturated thickness of the $(A)$ alluvial aquifer without drawdown constraints on Sparta aquifer wells and $(B)$ alluvial aquifer with drawdown constraints on Sparta aquifer wells within the Grand Prairie

14. Map showing percentage of desired pumping for scenario 3B 


\section{Tables}

1. Streambed conductance parameter values

2. Example comparison of estimated 5 -year water-use values in Jefferson County, Arkansas

\section{Conversion Factors}

Inch/Pound to SI

\begin{tabular}{lcl}
\hline \multicolumn{1}{c}{ Multiply } & By & \multicolumn{1}{c}{ To obtain } \\
\hline foot $(\mathrm{ft})$ & Length & meter $(\mathrm{m})$ \\
mile $(\mathrm{mi})$ & 0.3048 & kilometer $(\mathrm{km})$ \\
\hline & 1.609 & \\
\hline square mile $\left(\mathrm{mi}^{2}\right)$ & Area & hectare $(\mathrm{ha})$ \\
square mile $\left(\mathrm{mi}^{2}\right)$ & 259.0 & square $\mathrm{kilometer}\left(\mathrm{km}^{2}\right)$ \\
\hline & 2.590 & \\
\hline foot per day $(\mathrm{ft} / \mathrm{d})$ & Flow rate & meter per day $(\mathrm{m} / \mathrm{d})$ \\
cubic foot per second $\left(\mathrm{ft}^{3} / \mathrm{s}\right)$ & 0.3048 & cubic meter per second $\left(\mathrm{m}^{3} / \mathrm{s}\right)$ \\
million gallons per day $(\mathrm{Mgal} / \mathrm{d})$ & 0.02832 & cubic meter per second $\left(\mathrm{m}^{3} / \mathrm{s}\right)$ \\
\hline & 0.04381 & \\
\hline foot per day $(\mathrm{ft} / \mathrm{d})$ & Hydraulic conductivity & meter per day $(\mathrm{m} / \mathrm{d})$ \\
\hline
\end{tabular}

Vertical coordinate information is referenced to the North American Vertical Datum of 1988 (NAVD 88).

Horizontal coordinate information is referenced to the North American Datum of 1929 (NAD 29).

Altitude, as used in this report, refers to distance above the vertical datum.

*Transmissivity: The standard unit for transmissivity is cubic foot per day per square foot times foot of aquifer thickness [( $\left.\left.\mathrm{ft}^{3} / \mathrm{d}\right) / \mathrm{ft}^{2}\right] \mathrm{ft}$. In this report, the mathematically reduced form, foot squared per day $\left(\mathrm{ft}^{2} / \mathrm{d}\right)$, is used for convenience. 


\title{
Enhancements to the Mississippi Embayment Regional Aquifer Study (MERAS) Groundwater-Flow Model and Simulations of Sustainable Water-Level Scenarios
}

\author{
By Brian R. Clark', Drew A. Westerman'², and D. Todd Fugitt ${ }^{3}$
}

\section{Abstract}

Arkansas continues to be one of the largest users of groundwater in the Nation. As such, long-term planning and management are essential to ensure continued availability of groundwater and surface water for years to come. The Mississippi Embayment Regional Aquifer Study (MERAS) model was developed previously as a tool to evaluate groundwater availability within the Mississippi embayment, which encompasses much of eastern Arkansas where the majority of groundwater is used. The Arkansas Water Plan is being updated for the first time since 1990 and serves as the State's primary, comprehensive water-resources planning and guidance document. The MERAS model was selected as the best available tool for evaluation of specific water-use pumping scenarios that are currently being considered by the State of Arkansas. The model, developed as part of the U.S. Geological Survey Groundwater Resources Program's assessment of the Nation's groundwater availability, is proving to be invaluable to the State as it works toward development of a sustained yield pumping strategy. One aspect of this investigation was to evaluate multiple methods to improve the match of observed to simulated groundwater levels within the Mississippi River Valley alluvial and middle Claiborne (Sparta) aquifers in the MERAS model. Five primary methods were evaluated: (1) explicit simulation of evapotranspiration (ET), (2) upgrade of the Multi-Node Well (MNW2) Package, (3) geometry improvement within the Streamflow Routing (SFR) Package, (4) parameter estimation of select aquifer properties with pilot points, and (5) modification of water-use estimates. For the planning purposes of the Arkansas Water Plan, three scenarios were developed to evaluate potential future conditions: (1) simulation of previously optimized pumping values within the Mississippi River Valley alluvial and the middle Claiborne aquifers, (2) simulated prolonged effects of pumping at average recent (2000-5) rates, and

${ }^{1}$ U.S. Geological Survey, Fayetteville, Arkansas.

${ }^{2}$ U.S. Geological Survey, Little Rock, Arkansas.

${ }^{3}$ Arkansas Natural Resources Commission, Little Rock, Arkansas.
(3) simulation of drawdown constraints on most pumping wells.

The explicit simulation of ET indicated little, if any, improvement of model fit at the expense of much longer simulation time and was not included in further simulations. Numerous attempts to fully utilize the MNW2 Package were unsuccessful in achieving model stability, though modifications made to the water-use dataset remained intact. Final improvements in the residual statistics may be attributed to a single method, or a cumulative effect of all other methods (geometry improvement with the SFR Package, parameter estimation with pilot points, and modification of water-use estimates) attempted. The root mean squared error (RMSE) for all observations in the model is 22.65 feet ( $\mathrm{ft}$ ) over a range in observed hydraulic head of $741.66 \mathrm{ft}$. The RMSE for water-level observations in the Mississippi River Valley alluvial aquifer is $14.14 \mathrm{ft}$ (an improvement of almost $3 \mathrm{ft}$ ) over a range in observed hydraulic head of $297.25 \mathrm{ft}$. The RMSE for the Sparta aquifer is $32.02 \mathrm{ft}$ (an improvement of approximately $3 \mathrm{ft}$ ) over a range in observed hydraulic head of $634.94 \mathrm{ft}$.

Three scenarios were developed to utilize a steady-state version of the MERAS model. Scenario 1 was developed to use pumping values resulting from the optimization of baseline rates (typically 1997 pumping rates) from previous optimization modeling of the alluvial aquifer and the Sparta aquifer. Scenario 2 was developed to evaluate the prolonged effects of pumping from the alluvial aquifer at recent pumping rates. Scenario $3 \mathrm{~A}$ was designed to evaluate withdrawal limits from the alluvial aquifer by utilizing drawdown constraints equal to an altitude of approximately 50 percent of the predevelopment saturated thickness of the alluvial aquifer or $30 \mathrm{ft}$ above the bottom of the alluvial aquifer, whichever was greater. The results of scenario 1 indicate large waterlevel declines throughout the area of the alluvial aquifer, regardless of the substitution of the optimized pumping values from earlier model simulations. The results of scenario 2 also indicate large areas of water-level decline, as compared to half of the saturated thickness, throughout the alluvial aquifer. The results of scenario $3 \mathrm{~A}$ reveal some effects from the inclusion of multiple aquifers in a single simulation. The 
initial configuration of scenario $3 \mathrm{~A}$ resulted in water levels well below the defined drawdown constraint, and some areas of depleted aquifer (water levels that are near or below the bottom of the aquifer) in east-central Arkansas. A fourth simulation (scenario 3B) was configured to apply the same drawdown constraints from the alluvial aquifer wells to the Sparta aquifer wells in the depleted area. These drawdown constraints reduce leakage from the alluvial aquifer to the underlying Sparta aquifer. This configuration did not produce depleted areas within the alluvial aquifer. Scenarios $3 \mathrm{~A}$ and $3 \mathrm{~B}$ indicate that even when pumping is limited in the alluvial aquifer, water levels in the alluvial aquifer may continue to decline in some areas because of pumping in the underlying Sparta aquifer.

\section{Introduction}

Arkansas continues to be one of the largest users of groundwater in the Nation (Maupin and Barber, 2005). As such, long-term planning and management are essential to ensure continued availability of groundwater and surface water for years to come (Arkansas Natural Resources Commission, 2013a). One tool implemented as part of the planning process is a groundwater-flow model that can be used to represent recent (2007) and past conditions and evaluate changes in potential future conditions. The Mississippi Embayment Regional Aquifer Study (MERAS) model (fig. 1) of Clark and Hart (2009) and modified in Clark and others (2011) (model versions 1.0 and 1.1, respectively) was developed as a tool to evaluate groundwater availability within the Mississippi embayment, which encompasses much of eastern Arkansas where the majority of groundwater is used. The Arkansas Water Plan is being updated for the first time since 1990 and serves as the State's primary, comprehensive water-resources planning and guidance document (Arkansas Natural Resources Commission, 2013a). The MERAS model has been selected as the best available tool for evaluation of specific water-use pumping scenarios that are currently being considered by the State of Arkansas (Arkansas Natural Resources Commission, written commun., 2013). The model, developed as part of the U.S. Geological Survey (USGS) Groundwater Resources Program's assessment of the Nation's groundwater availability, is proving to be invaluable to the State in the development of a sustained yield pumping strategy. In an effort to continually improve the MERAS model calibration and, thus, the effectiveness of evaluating groundwater availability, the USGS, in cooperation with the Arkansas Natural Resources Commission (ANRC), evaluated multiple methods to improve the match of observed to simulated groundwater levels (reduction in residual error) within the Mississippi River Valley alluvial and middle Claiborne (Sparta) aquifers in the MERAS model. Because of the needs of the ANRC in preparation of the Arkansas Water Plan, the focus of reduction in residual error was primarily in Arkansas. Five methods for reducing the residual error were evaluated: (1) explicit simulation of evapotranspiration (ET) (net recharge was used in previous model versions), (2) upgrade of the MultiNode Well (MNW) Package, (3) geometry improvement within the Streamflow Routing (SFR) Package, (4) parameter estimation with pilot points, and (5) modification of water-use estimates.

For the analysis contained in this report, the MERAS groundwater-flow model (Clark and others 2011) (hereafter referred to as model version 1.1), which was modified from model version 1.0 (Clark and Hart, 2009) by decreasing the net recharge early in the simulation (predevelopment to the 1960s), was used as a starting point to introduce the enhancements. The MERAS model produced as a result of the enhancements is considered version 2.0 because of the modifications to the MNW Package and the introduction of pilot points. The purpose of this report is to document the multiple methods used to reduce model error, introduce the upgrade of the MNW2 Package and implementation of pilot points to create the MERAS model version 2.0, and provide the resulting calibration. Additionally, the report documents results of scenarios of prolonged pumping using (1) previously optimized pumping, (2) recent average pumping with reductions for surface-water diversions, and (3) drawdown constraints at 50 percent of the Mississippi River Valley alluvial aquifer predevelopment saturated thickness, or 30 $\mathrm{ft}$ above the bottom of the alluvial aquifer, whichever was greater. The scenarios are focused on the effects on water-level decline in the Mississippi River Valley alluvial aquifer and the middle Claiborne (Sparta) aquifer within the State boundary of Arkansas.

The MERAS model area is approximately 78,000 square miles $\left(\mathrm{mi}^{2}\right)$ and includes eight States with approximately 6,900 miles of simulated streams, 70,000 well locations, and 10 primary hydrogeologic units (Clark and Hart, 2009). The calibration period extends from January 1, 1870, to April 1,2007 , for a total of 137 years and 69 stress periods. The first stress period is simulated as steady state to represent predevelopment conditions. The MERAS model is the only groundwater-flow model currently available to simulate fresh groundwater in all adjacent States that are part of the Mississippi embayment. Therefore, the MERAS model provides a unique tool that is useful for interstate sustainability issues while focusing on a particular State, which is Arkansas in this investigation. 


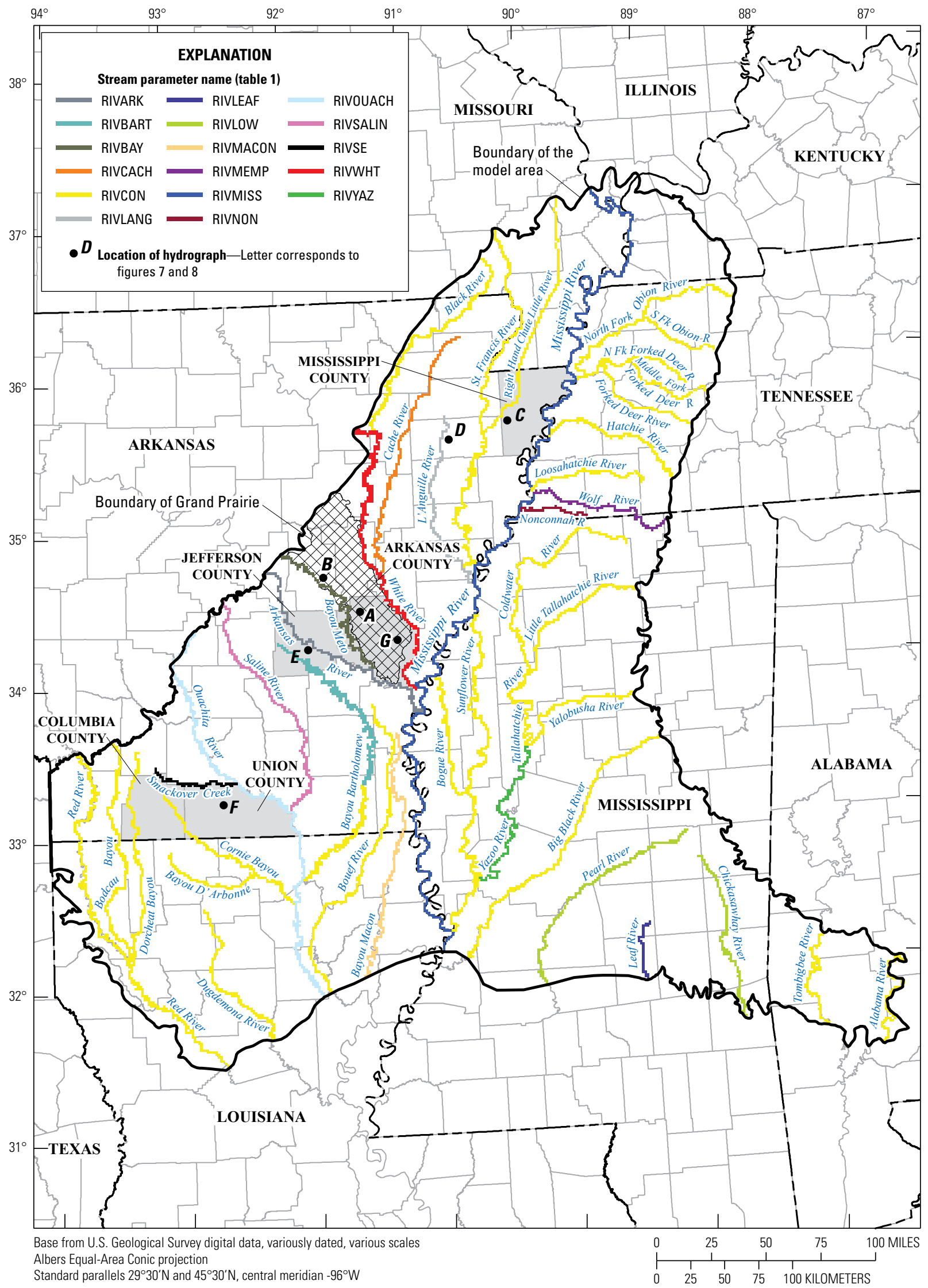

Figure 1. Location of the Mississippi Embayment Regional Aquifer Study model area, with the primary focus of improvement within the State boundary of Arkansas. 


\section{Methods}

The explicit simulation of evapotranspiration (ET) required estimates of ET rates for the calibration period from 1870 to 2007 . Conceptually, by explicitly simulating ET, the model may more closely approximate the true physical processes at work in the groundwater system and, thus, improve the model calibration, particularly in the early time period of the simulation. ET rates for the simulation period from 1870 to 2007 were estimated from temperature based Potential ET (PET) methods (Hamon, 1961) and adjusted to represent ET at the water table. Grids of maximum and minimum temperature were downloaded from the Parameterelevation Regression on Independent Slopes Model (PRISM) for the period from 1895 to 2007 (Daly and others, 2000; PRISM Climate Group, 2011). An average of the earliest available temperature grids (1895-97) was used to estimate PET rates for the simulation period from 1870 to 1894 . PET rates were calculated using the Hamon method (Hamon, 1961), a method recommended by $\mathrm{Lu}$ and others (2005) for regional applications in the Southeastern United States. Grids of PET values were developed for each stress period of the MERAS model version 2.0 and further adjusted through multipliers similar to those used in the estimation of recharge in the MERAS model version 1.0 to achieve representative values of ET at the water table using the ET Package of MODFLOW-2005 (Harbaugh, 2005).

Recent and ongoing advancements in water-resource models allow for explicit simulation of water-management concerns such as multiscreened wells. The MERAS model version 1.1 incorporates the Multi-Node Well 1 (MNW1) Package (Halford and Hanson, 2002) to represent wells completed in multiple aquifers. Recent modifications to the MNW Package (referred to as MNW2) (Konikow and others, 2009) include new output options to more easily evaluate the flow of water through MNWs and, thus, evaluate the effect on the groundwater system. The MNW dataset used in the MERAS model versions 1.0 and 1.1 contained well fields in which each well within the same well field was given the same identifier, which is not compatible with the MNW2 Package. The duplicate well identifiers were replaced with unique identifiers in MERAS model version 2.0 or, in some cases, actual duplicate withdrawals were removed. The MERAS model (all versions) discretized selected hydrogeologic units (such as the middle Claiborne [Sparta] aquifer and the lower Wilcox aquifer [Clark and others, 2011, table 1]) into multiple model layers. Because these units span multiple layers, and the location of well screens in these units was not well known, many of the wells were input into the model as MNWs rather than input as a withdrawal from a single layer (representing a discrete zone within a single hydrogeologic unit). While this method of input accounts for the uncertainty in well screen placement, it adds complexity to the simulation that may not be warranted. These MNWs were replaced by withdrawals from a single layer (the lowermost layer representing each hydrogeologic unit) and simulated as a single-node well in MNW2 in model version 2.0. In the MERAS model version 1.1 in the Grand Prairie area (fig. 1), wells designated with the middle Claiborne aquifer (hereafter referred to as the Sparta aquifer) as the primary aquifer were simulated as extending from the Mississippi River Valley alluvial aquifer (hereafter referred to as the alluvial aquifer) to the lower part of the Sparta aquifer with the MNW Package. However, in the MERAS model version 2.0, these wells were specified only in the Sparta aquifer (layer 7) and were simulated using a single node in MNW2.

The SFR Package also was designated for improvement, particularly the geometry of selected streams simulated by the package (Niswonger and Prudic, 2005). As noted in Clark and Hart (2009), stream widths in the MERAS model version 1.0 were determined from 1:24,000 topographic maps at the midpoint of the stream length simulated in the model area. For the MERAS model version 2.0, the USGS obtained measured cross-section data from the U.S. Army Corps of Engineers on the Arkansas and Mississippi Rivers (fig. 1). From these cross-section data, more accurate estimates of mean stream width and depth were calculated. Additional river parameters representing Bayou Bartholomew, Bayou Macon, Bayou Meto, Leaf River, Nonconnah River, and Yazoo River (fig. 1) also were created to represent potential differences in streambed conductance. Many streambed conductances were modified from the original calibrated values to reflect changes in parameterization and geometry (table 1).

For the MERAS model version 2.0, the benefits of pilot points were evaluated (Doherty, 2003), particularly in the storage and hydraulic conductivity properties of the shallow alluvial aquifer and the deeper confined system of the Sparta aquifer where small changes in storage and hydraulic conductivity can produce large changes in simulated groundwater levels. The MERAS model versions 1.0 and 1.1 used discrete zones to represent aquifer properties and stresses (such as hydraulic conductivity, storage, vertical anisotropy, and recharge), whereas version 2.0 used pilot points to allow for greater flexibility in the spatial assignment of aquifer properties. Essentially, each point at a specified location is assigned a value of a hydraulic property, which can change throughout the calibration process. A hydraulic property value for each model cell is interpolated based on the values of surrounding pilot points, which can serve to spatially vary the properties in a gradational manner, rather than discrete zones of hydraulic properties. More information on pilot points and the geostatistical methods are available in Doherty (2011). Pilot points were distributed uniformly across the alluvial and Sparta aquifers at a spacing of approximately 5 miles (figs. 2 and 3), resulting in a total of 2,056 pilot points for the alluvial and other surficial aquifers (which included alluvial and terrace deposits beyond the Mississippi River Valley alluvial aquifer) and 2,271 pilot points for the Sparta aquifer. Additional pilot points were generated for 
Table 1. Streambed conductance parameter values.

[All units are in feet per day; MERAS, Mississippi Embayment Regional Aquifer Study]

\begin{tabular}{lllcc}
\hline \multicolumn{1}{c}{ River name } & $\begin{array}{c}\text { MERAS model version 1.1 } \\
\text { parameter name }\end{array}$ & $\begin{array}{c}\text { MERAS model version 2.0 } \\
\text { parameter name }\end{array}$ & $\begin{array}{c}\text { MERAS model version 1.1 } \\
\text { parameter value }\end{array}$ & $\begin{array}{c}\text { MERAS model version 2.0 } \\
\text { parameter value }\end{array}$ \\
\hline Selected rivers & RIVCON & RIVCON & $1.458 \times 10^{-1}$ & $2.458 \times 10^{-1}$ \\
Arkansas River & RIVARK & RIVARK & $9.0 \times 10^{-2}$ & 1.09 \\
Mississippi River & RIVMISS & RIVMISS & 15.4 & $1.0 \times 10^{-2}$ \\
Ouachita River & RIVOUACH & RIVOUACH & 16.1 & 16.1 \\
White River & RIVWHT & RIVWHT & 13.8 & 1.80 \\
L'Anguille River & RIVLANG & RIVLANG & $9.9 \times 10^{-1}$ & $1.0 \times 10^{-2}$ \\
Saline River & RIVSALIN & RIVSALIN & 1.03 & 0.10 \\
Cache River & RIVCACH & RIVCACH & 1.14 & 1.14 \\
Selected rivers & RIVLOW & RIVLOW & $1.099 \times 10^{-2}$ & $1.099 \times 10^{-2}$ \\
Wolf River & RIVMEMP & RIVMEMP & 1.00 & 0.10 \\
Bayou Meto & RIVLOW & RIVBAY & $1.099 \times 10^{-2}$ & $10.001-0.1$ \\
Nonconnah River & RIVMEMP & RIVNON & 1.00 & 0.10 \\
Bayou Macon & RIVCON & RIVMACON & $1.458 \times 10^{-1}$ & $1.458 \times 10^{-1}$ \\
Bayou Bartholomew & RIVCON & RIVBART & $1.458 \times 10^{-1}$ & $4.0 \times 10^{-2}$ \\
Leaf River & RIVCON & RIVLEAF & $1.458 \times 10^{-1}$ & $1.0 \times 10^{-2}$ \\
Yazoo River & RIVCON & RIVYAZ & $1.458 \times 10^{-1}$ & $1.2 \times 10^{-1}$ \\
Smackover Creek & RIVCON & RIVSE & $1.458 \times 10^{-1}$ & $2.0 \times 10^{-1}$ \\
\hline Val & & & \\
\hline
\end{tabular}

${ }^{1}$ Value linearly interpolated from upstream to downstream.

the Vicksburg-Jackson confining unit (fig. 4) and recharge multiplier values (fig. 5). Initial storage values for each pilot point were generated by interpolating a continuous surface between estimated storage values from aquifer tests. Initial values of hydraulic conductivity and recharge multiplier values were duplicated from the zonal values used in the MERAS model version 1.0. The value of each pilot point was then manually and automatically adjusted using a program (PEST; Doherty, 2008) to estimate optimal parameter values through a series of model simulations. After each model simulation, simulated hydraulic-head values were compared automatically to measured hydraulic-head values. The simulations continued until a best fit between simulated hydraulic head and measured hydraulic head was attained. The calibration approach used in the simulation was similar to that used by Clark and Hart (2009), which took advantage of Tikhonov regularization (Tikhonov, 1963; Doherty, 2003; Fienen and others, 2009) and hybrid singular value decomposition (Tonkin and Doherty, 2005; Hunt and others, 2007), also referred to as SVD-Assist in Doherty (2008). These methods can serve to constrain the parameter values so that large discrepancies in hydraulic properties are minimized, and parameters are combined in a way to make automated parameter estimation feasible when the number of pilot points (thus parameters) can easily number in the thousands. 


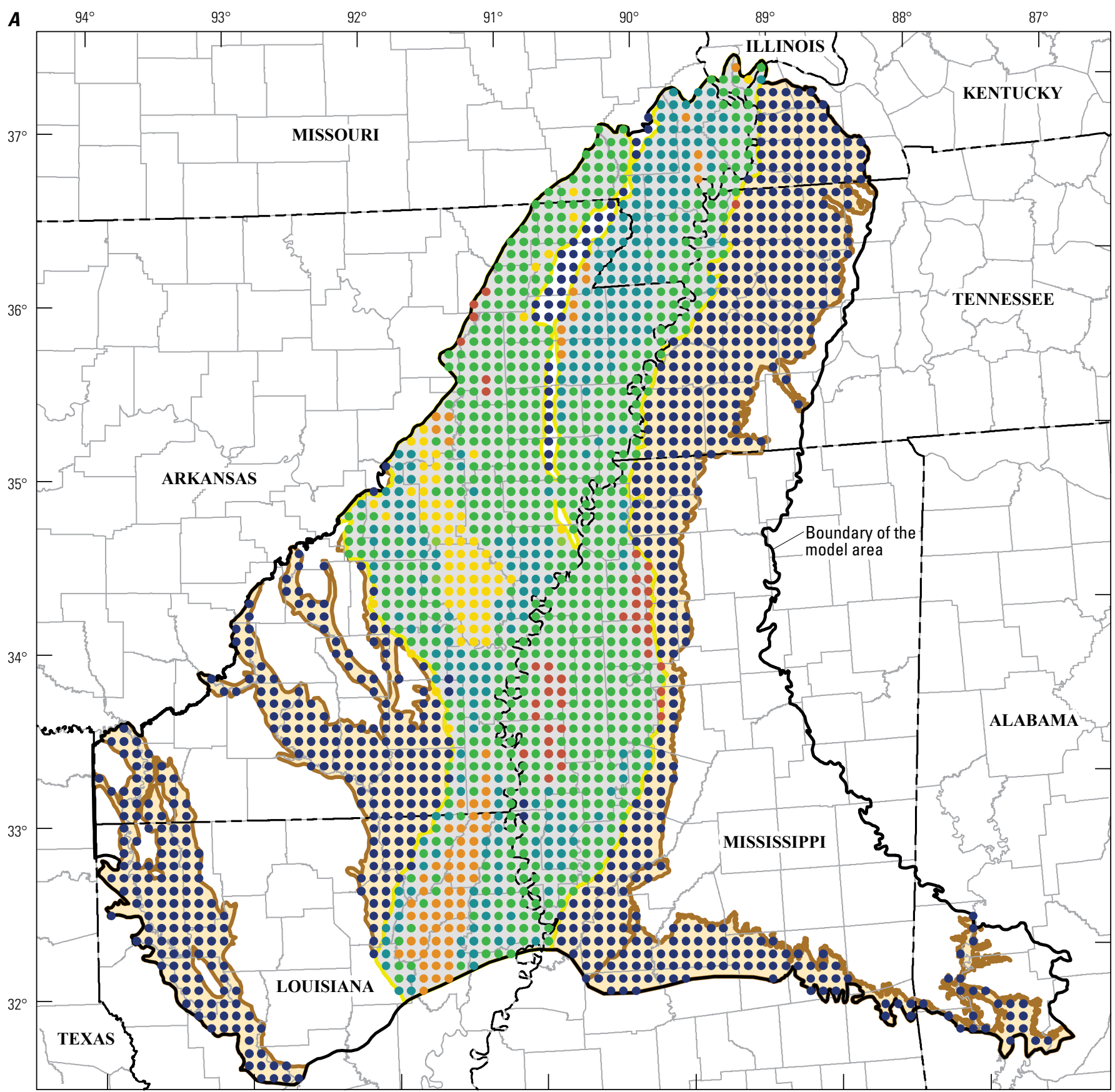

Base from U.S. Geological Survey digital data, variously dated, various scales Albers Equal-Area Conic projection

Standard parallels $29^{\circ} 30^{\prime} \mathrm{N}$ and $45^{\circ} 30^{\prime} \mathrm{N}$, central meridian $-96^{\circ} \mathrm{W}$

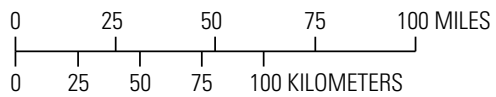

\section{EXPLANATION}

\begin{tabular}{|lcl|}
\hline $\begin{array}{c}\text { Mississippi River Valley } \\
\text { alluvial aquifer }\end{array}$ & $\begin{array}{c}\text { Pilot-point locations with associated value of } \\
\text { hydraulic conductivity, in feet per day }\end{array}$ \\
\hline Surficial aquifer & 550.1 to $600.0 \quad 150.1$ to 250.0 \\
\hline & 450.1 to $550.0 \quad 50.1$ to 150.0 \\
\hline & 350.1 to $450.0 \quad-10.0$ to 50.0 \\
& 250.1 to 350.0
\end{tabular}

Figure 2. Pilot-point locations and values of $(A)$ hydraulic conductivity and $(B)$ specific storage used to represent the alluvial (and other surficial) aquifer. 


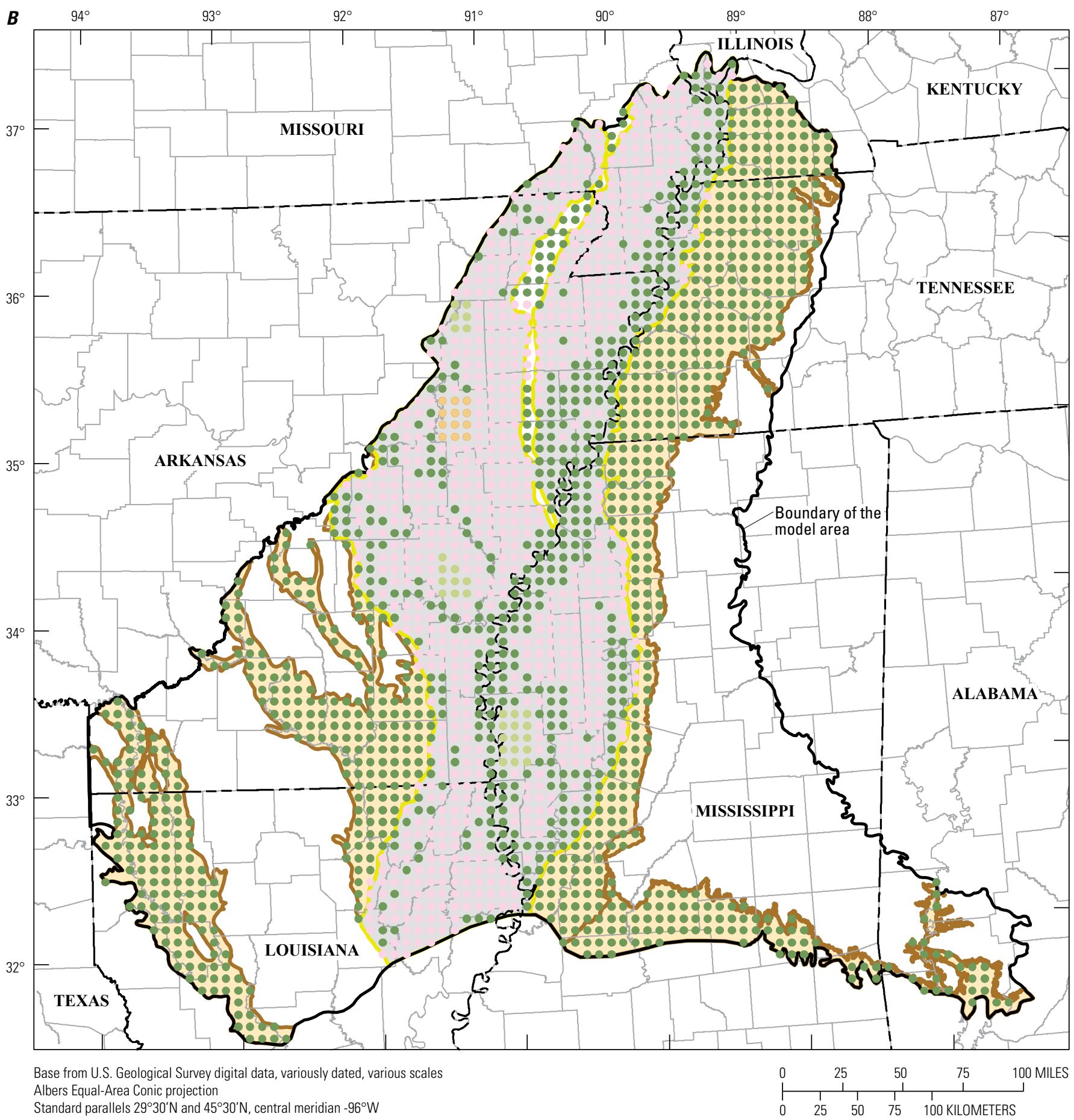

EXPLANATION

\begin{tabular}{|c|c|c|c|}
\hline $\begin{array}{l}\text { Mississippi River Valley } \\
\text { alluvial aquifer }\end{array}$ & \multicolumn{3}{|c|}{$\begin{array}{l}\text { Pilot-point locations with associated value of } \\
\text { value of specific storage, in } 1 \text { per foot }\end{array}$} \\
\hline \multirow[t]{4}{*}{ Surficial aquifer } & - 0.31 to 0.35 & & 0.11 to 0.15 \\
\hline & 0.26 to 0.30 & 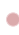 & 0.06 to 0.10 \\
\hline & 0.21 to 0.25 & a & 0.00 to 0.05 \\
\hline & 0.16 to 0.20 & & \\
\hline
\end{tabular}

Figure 2. Pilot-point locations and values of $(A)$ hydraulic conductivity and $(B)$ specific storage used to represent the alluvial (and other surficial) aquifer.-Continued 


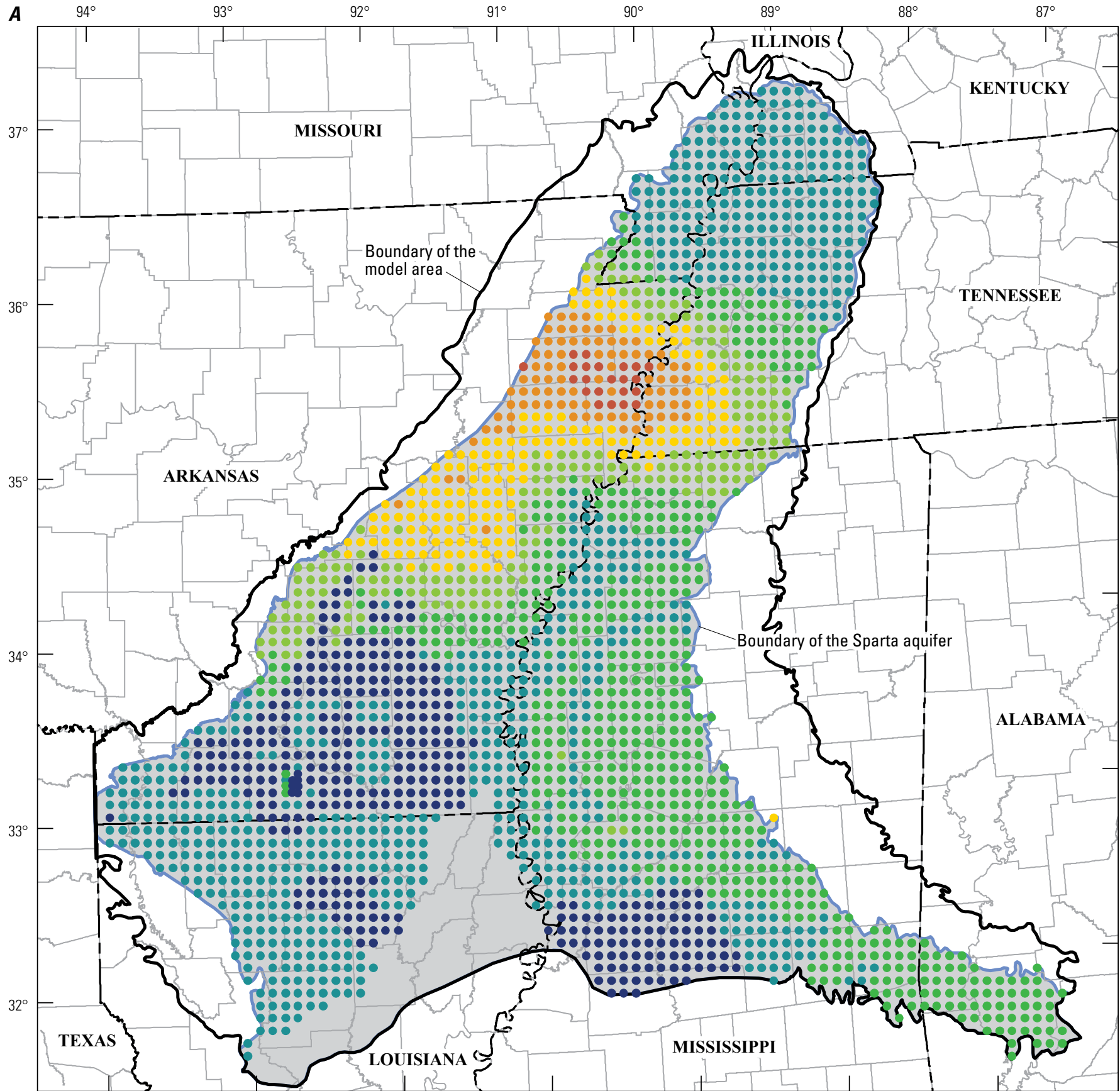

Base from U.S. Geological Survey digital data, variously dated, various scales Albers Equal-Area Conic projection

Standard parallels $29^{\circ} 30^{\prime} \mathrm{N}$ and $45^{\circ} 30^{\prime} \mathrm{N}$, central meridian $-96^{\circ} \mathrm{W}$

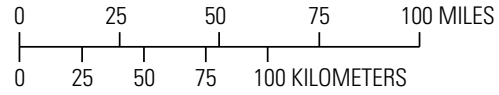

EXPLANATION

$\begin{aligned} & \text { Pilot-point locations with associated value of } \\ & \text { hydraulic conductivity, in feet per day }\end{aligned}$
$\begin{array}{ll}120.1 \text { to } 140.0 & -40.1 \text { to } 60.0 \\ 100.1 \text { to } 120.0 & \text { - } 20.1 \text { to } 40.0 \\ 80.1 \text { to } 100.0 & \text { - } 0.1 \text { to } 20.0 \\ 60.1 \text { to } 80.0 & \end{array}$

Figure 3. Pilot-point locations and values of $(A)$ hydraulic conductivity and $(B)$ specific storage used to represent the Sparta aquifer. 


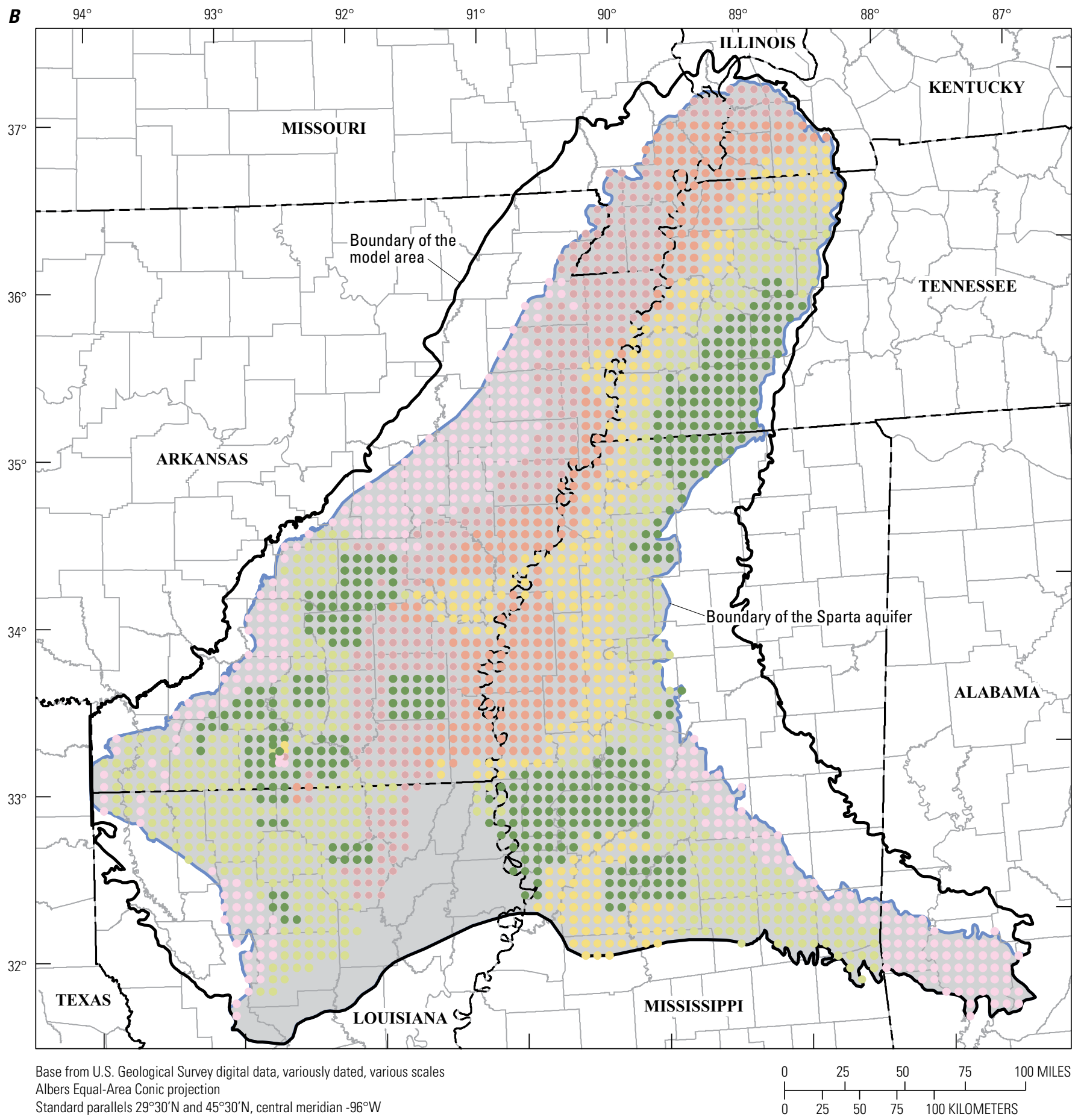

EXPLANATION

$\begin{aligned} & \text { Pilot-point locations with associated value of specific } \\
& \text { storage, in } 1 \text { per foot }\end{aligned}$
\begin{tabular}{ll}
0.0001001 to 0.1000054 & 0.0000101 to 0.0000150 \\
0.0000301 to 0.0001000 & 0.0000076 to 0.0000100 \\
\hline 0.0000151 to 0.0000300 & -0.0000001 to 0.0000075
\end{tabular}

Figure 3. Pilot-point locations and values of $(A)$ hydraulic conductivity and $(B)$ specific storage used to represent the Sparta aquifer-Continued 


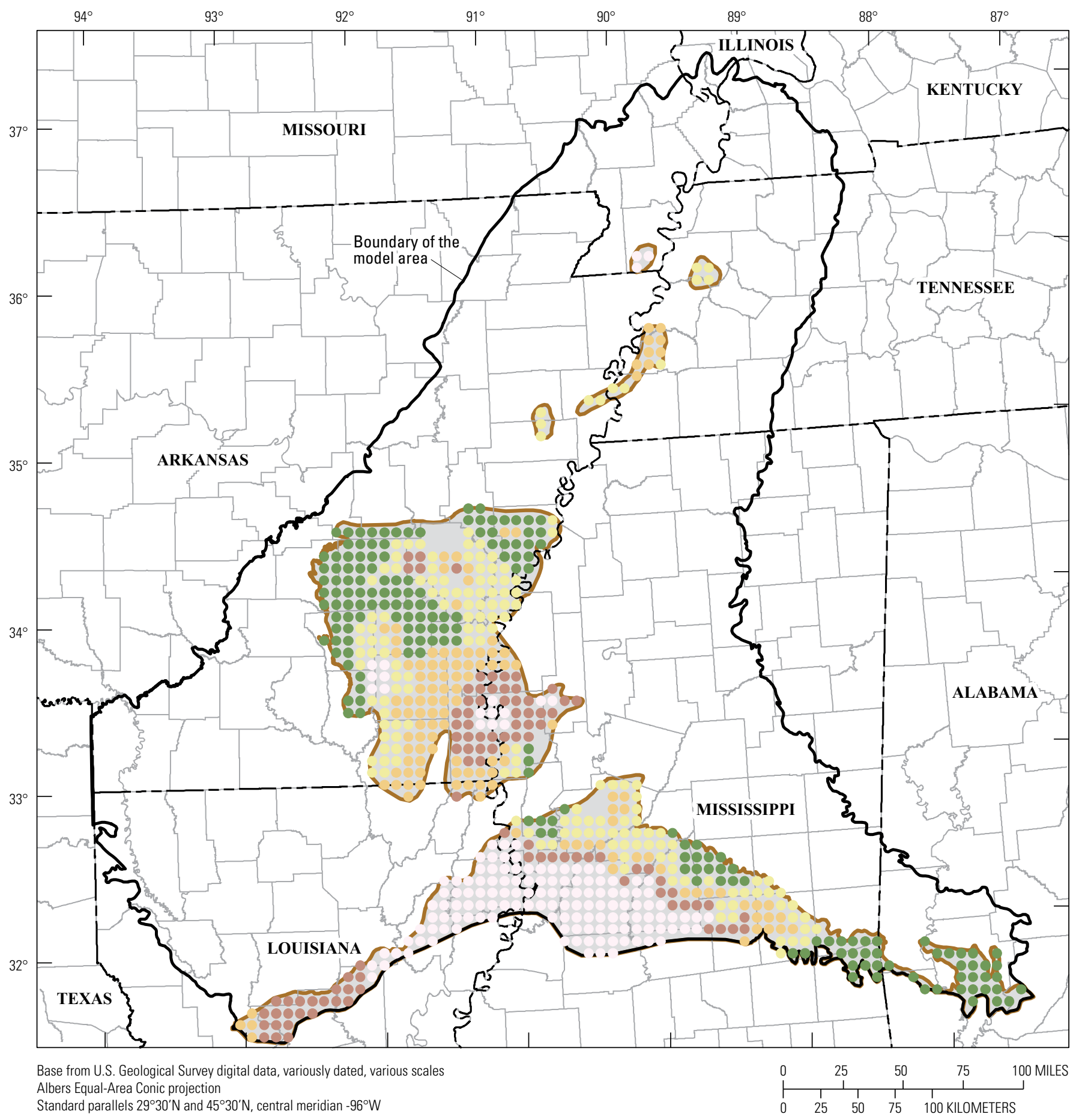

Standard parallels $29^{\circ} 30^{\prime} \mathrm{N}$ and $45^{\circ} 30^{\prime} \mathrm{N}$, central meridian $-96^{\circ} \mathrm{W}$

\section{EXPLANATION}

Pilot-point locations with associated value of confining unit

vertical anisotropy, ratio of horizontal to

vertical hydraulic conductivity

500.0

$1,000.1$ to $1,250.0$

500.1 to 750.0

$1,250.1$ to $1,475.0$

750.1 to $1,000.0$

Figure 4. Pilot-point locations and values of vertical anisotropy used to represent the Vicksburg-Jackson confining unit. 
$A$

A

$94^{\circ}$

$93^{\circ}$

$92^{\circ}$

$91^{\circ}$

$90^{\circ}$

$\begin{array}{lll}89^{\circ} & 88^{\circ} & 87^{\circ}\end{array}$

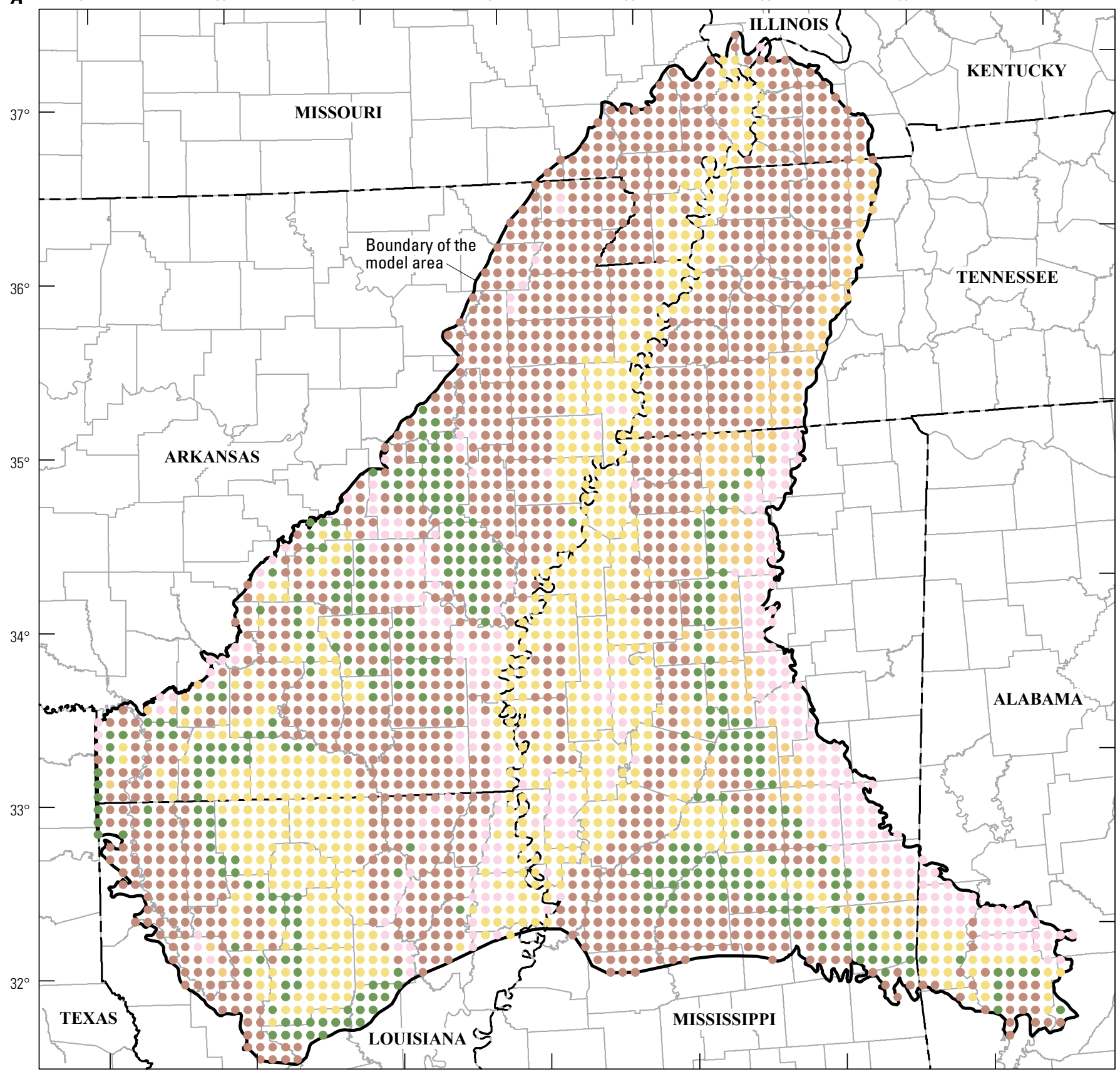

Base from U.S. Geological Survey digital data, variously dated, various scales Albers Equal-Area Conic projection

Standard parallels $29^{\circ} 30^{\prime} \mathrm{N}$ and $45^{\circ} 30^{\prime} \mathrm{N}$, central meridian $-96^{\circ} \mathrm{W}$

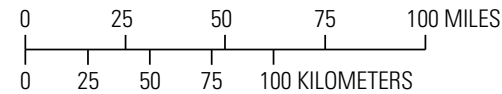

EXPLANATION

$\begin{aligned} & \text { Pilot-point locations with associated } \\ & \text { recharge multiplier }\end{aligned}$
$\begin{array}{ll}0.0001 \text { to } 0.0010 & 0.0101 \text { to } 0.0500 \\ 0.0011 \text { to } 0.0050 & 0.0501 \text { to } 0.0706 \\ 0.0051 \text { to } 0.0100 & \end{array}$

Figure 5. Pilot-point locations and values of recharge multipliers. 
During a review of estimated water-use values used in the previous MERAS models, some published values in the 5-year water-use reports (Holland, 1987; Holland, 1993; Lovelace and Johnson, 1996; Lurry, 1987; Walter, 1982) were found to have corrected values estimated after the initial publication date. Additionally, simulated hydraulic head values in select counties such as Columbia, Jefferson, and Union County, Ark. (fig. 1), indicated potential discrepancies with the estimated water-use values from the Sparta aquifer. Upon further comparison with the time-series data, modifications were made to values representing pumping from the Sparta aquifer for select years. As an example, published water-use estimates for Jefferson County, Ark. (Holland, 1987), used in the MERAS model version 1.1 show a general increase in water use from 1965 to 1980 , followed by a dramatic decrease (from 71.1 Mgal/day to $42.4 \mathrm{Mgal} /$ day from 1980 to 1985 ), then another increase (1990 to 1995), followed by another decrease (1995 to 2000) (table 2). Measured water levels in Jefferson County, Ark., used in the MERAS models show an overall steady decline from the 1960s through the early 2000s (Schrader, 2009, fig. 4, p. 16). An increase in water level of approximately $25 \mathrm{ft}$ occurs between about 1982 and 1986, with most of the increase occurring from about 1983 to 1986 , which may indicate a decrease in water use for those years. However, because stress periods in the MERAS models represent multiple years in many instances, a large reduction in water use for a single year may not adequately represent average pumping conditions over longer stress periods in the model. Corrections to the 5-year reported values also affected the trend analysis described in Clark and Hart (2009) by modifying the best fit lines based on the updated 5-year values. As a result, corrected values for the 5-year data and trend-estimated data were updated in the water-use data

Table 2. Example comparison of estimated 5-year water-use values in Jefferson County, Arkansas.

[All values are in million gallons per day]

\begin{tabular}{ccc}
\hline Year & Model version 1.1 & Model version 2.0 \\
\hline 1960 & 52.4 & 52.4 \\
1965 & 44.4 & 44.4 \\
1970 & 59.3 & 59.3 \\
1975 & 53.8 & 53.8 \\
1980 & 71.1 & 71.1 \\
1985 & 42.4 & 65.0 \\
1990 & 78.5 & 63.8 \\
1995 & 53.9 & 53.9 \\
2000 & 50.2 & 50.2 \\
2005 & 50.4 & 50.4 \\
\hline
\end{tabular}

${ }^{1}$ Represents original published values from 5-year water-use reports (Halberg, 1972, 1977; Halberg and Stephens, 1966; Holland, 1987, 1993, 1999, 2004, 2007; Holland and Ludwig, 1981; Stephens and Halberg, 1961). simulated by the MERAS model version 2.0 and incorporated using the methods described in Clark and Hart (2009). While the modifications to water use in the model typically resulted in a positive effect on simulated heads, the cumulative change in water use in the model was not substantial compared to the MERAS model version 1.1.

\section{Evaluation of Model Enhancements}

The evaluation of the goodness of model fit is described below through a comparative analysis of root mean square errors (RMSEs) documented in Clark and others (2011) of MERAS model version 1.1. Five primary methods were evaluated to improve the MERAS model, which include (1) explicit simulation of ET, (2) upgrade of the MNW Package, (3) geometry improvement within the SFR Package, (4) parameter estimation with pilot points, and (5) modification of water-use estimation. Any improvement in the simulated hydraulic head value may be attributed to a single method, or a cumulative effect of all methods, with the exception of the explicit simulation of ET. The explicit simulation of ET indicated little, if any, improvement of model fit at the expense of much longer simulation time and was not included in further simulations. Numerous attempts to fully use the MNW2 package were unsuccessful in achieving model stability; therefore, while the MERAS model version 2.0 continues to implement MNW1, all modifications to the pumping dataset were retained, such as removal of duplicate well identifiers and the simplification of withdrawals from a single layer as described in the "Methods" section.

\section{Comparison of Simulated and Observed Values}

For comparative purposes to MERAS model version 1.1, the RMSE for observed groundwater levels compared to simulated groundwater levels was computed for each year. The RMSE for all observations in model version 2.0 is 22.65 $\mathrm{ft}$ over a range in observed hydraulic head of $741.66 \mathrm{ft}$ over the entire model area, where the range equals the difference between the highest and lowest observed hydraulic head. The RMSE for alluvial observations in model version 2.0 is $14.14 \mathrm{ft}$ (an improvement of almost $3 \mathrm{ft}$ ) over a range in observed hydraulic head of $297.25 \mathrm{ft}$ over the entire model area. Likewise, the RMSE for the Sparta aquifer is $32.02 \mathrm{ft}$ (an improvement of approximately $3 \mathrm{ft}$ ) over a range in observed hydraulic head of $634.94 \mathrm{ft}$. RMSE values between the MERAS model version 1.1 and 2.0 are compared in figure 6 . The RMSE values derived from MERAS model version 2.0 are similar to or less than RMSE values from the previous MERAS model version for the alluvial aquifer for all time periods (fig. 6). Some of the largest improvements in RMSE values are from the late 1940s and early 1950s. Simulated streamflow is generally similar to the MERAS model version 1.1 and is not shown. 


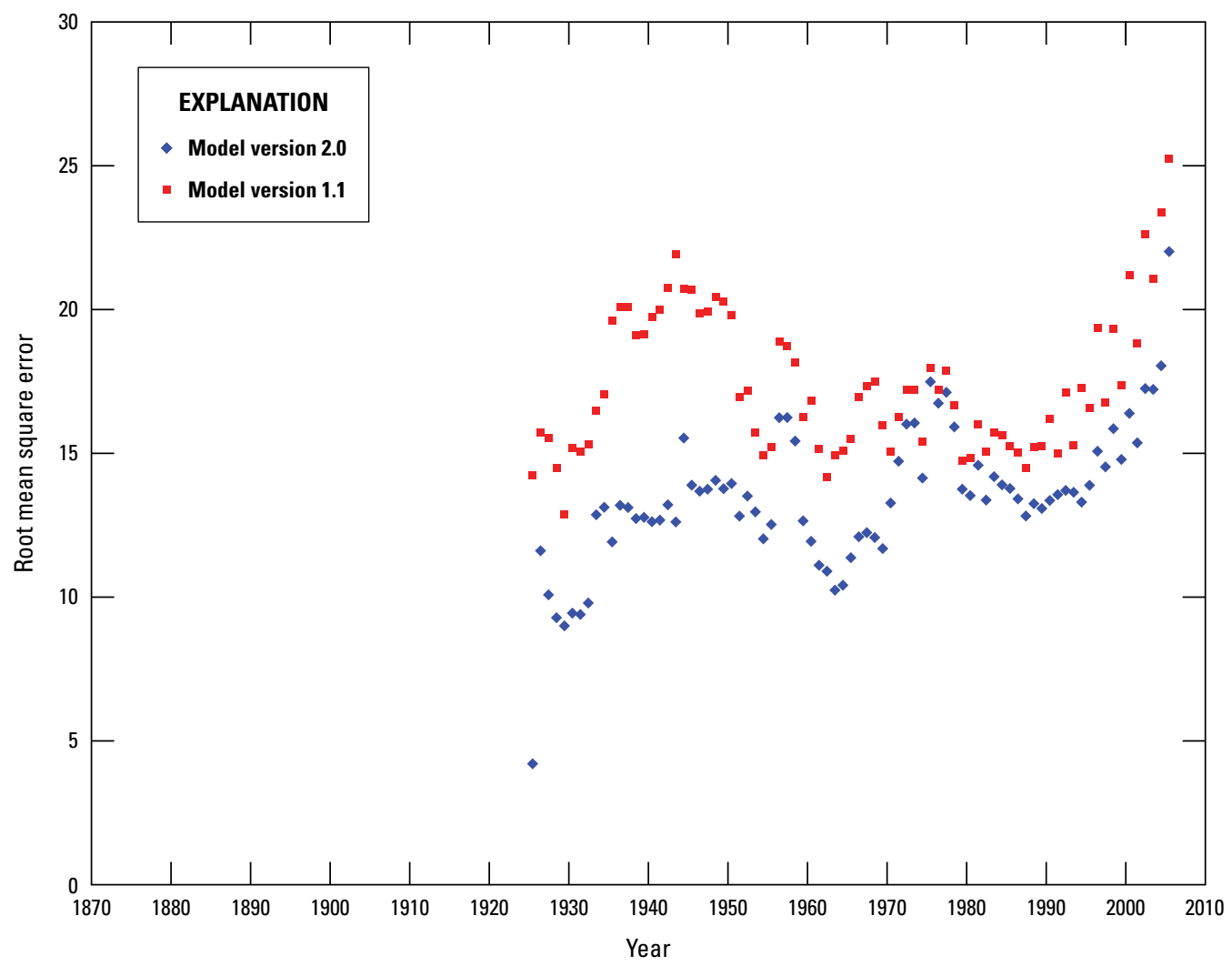

Figure 6. Comparison of root mean square error of the Mississippi River Valley alluvial aquifer between the Mississippi Embayment Regional Aquifer Study (MERAS) model versions 1.1 and 2.0.

\section{Simulated and Observed Hydrographs}

Simulated and observed hydrographs of hydraulic head were included in the same manner as presented in Clark and Hart (2009) for wells within Arkansas (fig. 7; locations of wells are included on fig. 1). The location and fit of simulated to observed data of the selected hydrographs give an indication of any spatial bias that may be present in the simulation, which is similar to that presented in MERAS model 1.0 (Clark and Hart, 2009). Simulated hydrographs generally are similar to those of MERAS model versions 1.0 and 1.1; though there are subtle improvements in the match to observed hydrographs in Arkansas, Union, and Mississippi Counties in Arkansas (fig. 1). The MERAS model version 1.0 simulated a waterlevel decline in the last 10 to 20 years of the simulation period for Mississippi County, whereas MERAS model version 2.0 simulated less decline as indicated by the observed values. The hydrograph in Arkansas County continues to show substantial declines in the simulated hydraulic head. While much effort was applied to improve the model fit in this area, which might require large changes to parameter values, no justifiable reason was found to make these changes based on available aquifer test data. Error in reported water-use amounts is another possible explanation (for the current lack of fit) and is discussed further in the following section "Effects of Water Use Estimation Error." The observed hydrograph in Arkansas County also may indicate the influence of a boundary condition such as a small stream or lake, which is difficult to adequately represent in large, regional flow models. Another hydrograph difference can be found in Lonoke County, Ark., where the simulated hydraulic head varies by more than $20 \mathrm{ft}$ in the last 20 years of the model simulation. This variability is caused by the irrigation and nonirrigation stress periods used in the later part of the simulation. In light of these differences between simulated and observed values, all hydrographs show good general agreement in the direction and changes in water level. The hydrograph in Mississippi County indicates very little deviation from historical water levels, and the simulation matches this well. Additionally, the hydrograph from Union County, Ark., indicates large waterlevel declines followed by recovery, which the simulation mimics in a subdued form. 
A. Arkansas County, Arkansas

Mississippi River Valley alluvial aquifer

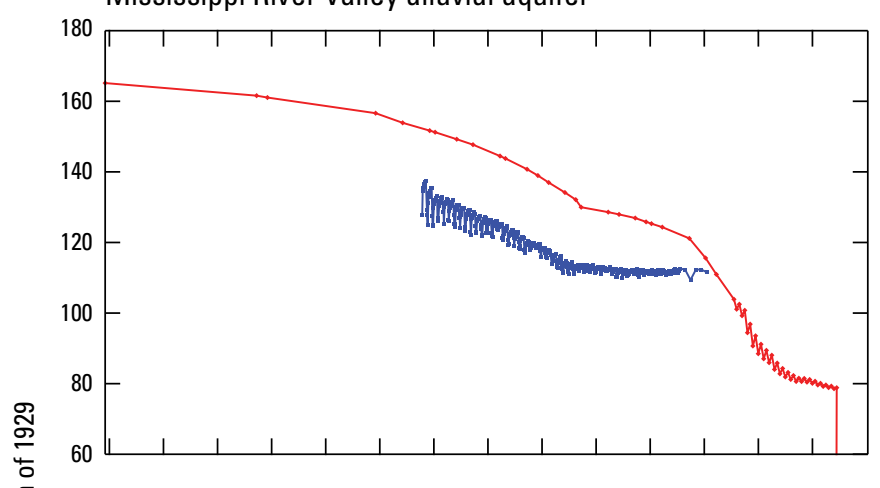

C. Mississippi County, Arkansas

Mississippi River Valley alluvial aquifer

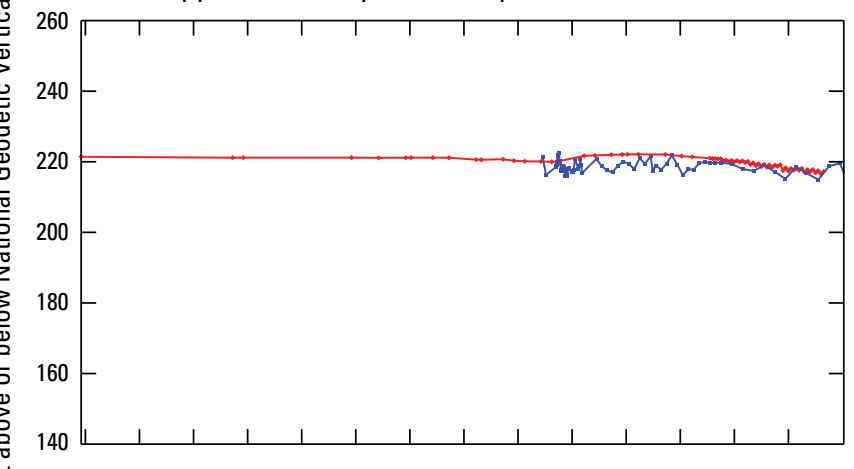

E. Jefferson County, Arkansas

Sparta aquifer

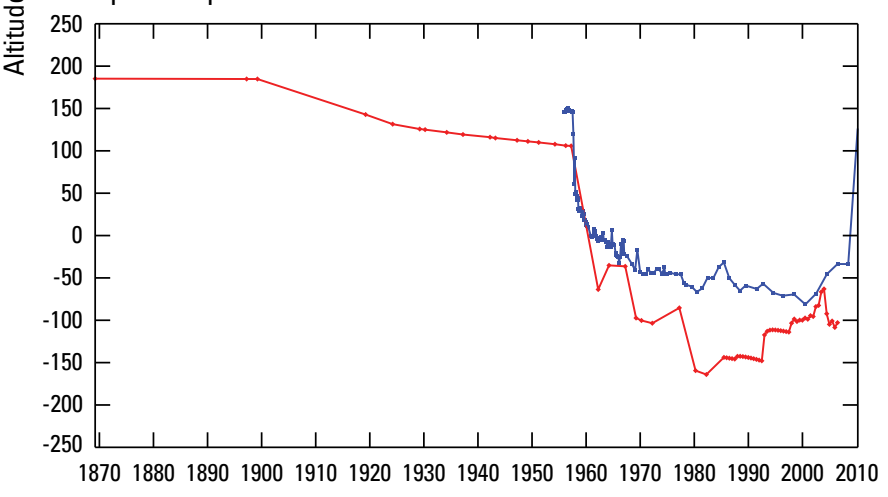

Year
B. Lonoke County, Arkansas

Mississippi River Valley alluvial aquifer

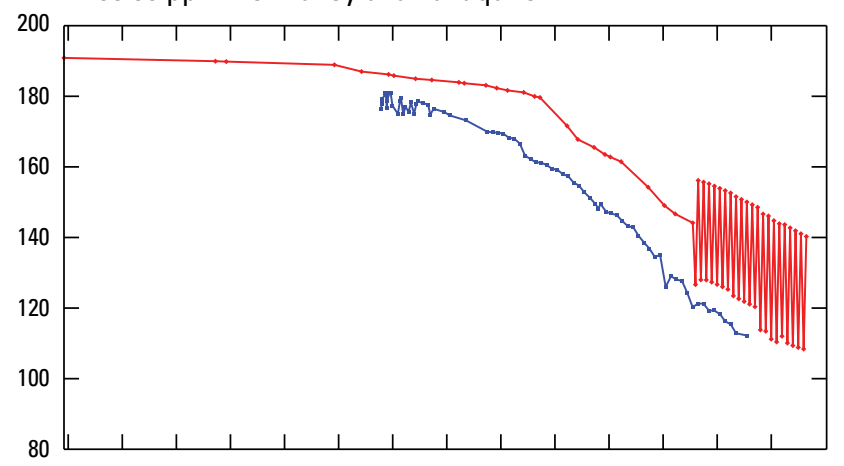

D. Poinsett County, Arkansas

Mississippi River Valley alluvial aquifer

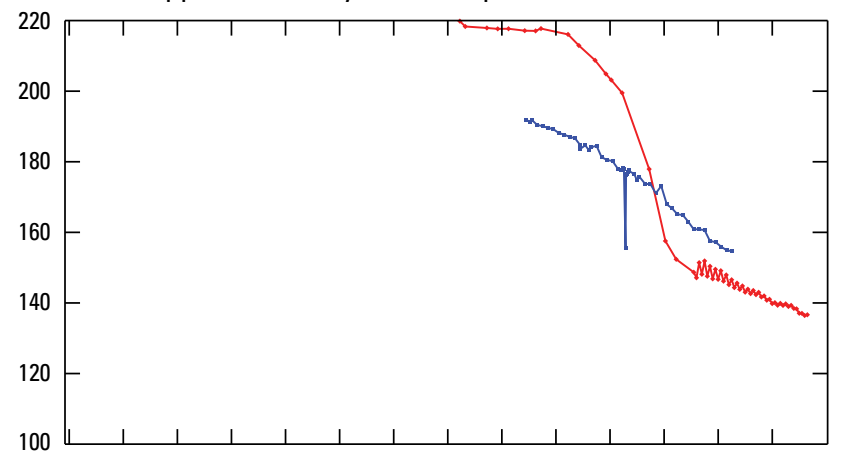

F. Union County, Arkansas

Sparta aquifer

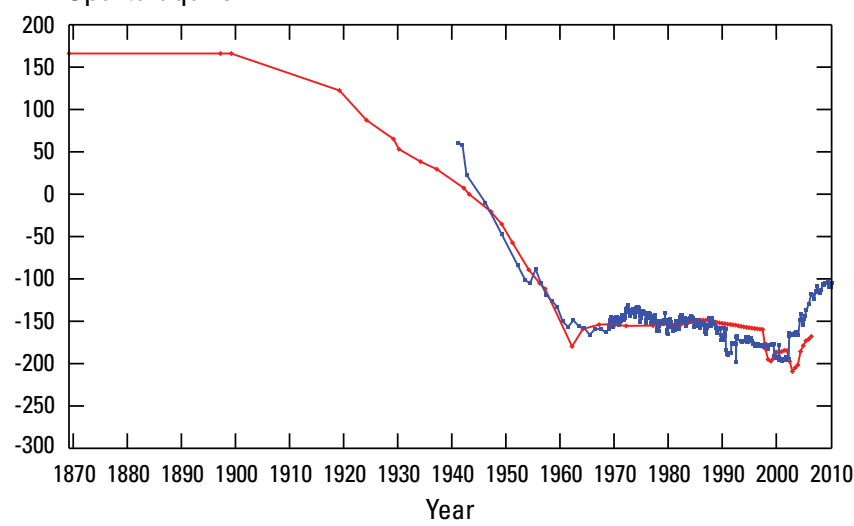

\section{EXPLANATION}

Figure 7. Simulated and observed hydrographs of hydraulic head in selected wells. Letters correspond to figure 1. 


\section{Effects of Water-Use Estimation Error}

Water-use information in Arkansas is reported yearly by many industrial, municipal, and agricultural entities using the groundwater or surface-water sources (Arkansas Natural Resources Commission, 2013c). In some instances, the reported irrigation amount may represent a rough estimate of the actual amount of water used because of estimating flow from unmetered wells or approximating the depth of water applied over a given extent of crop. To explore the effect of these reported values on simulated heads, water use for all alluvial aquifer wells was reduced by 50 percent for each year after 1982. For some observation wells in the alluvial aquifer, this reduction in pumping resulted in groundwaterlevel increases of about $20 \mathrm{ft}$. More drastic differences of $40 \mathrm{ft}$ or more were simulated in some areas of historical groundwater decline, such as a hydrograph from east-central Arkansas County, Ark. (fig. 8). Overall, the new RMSE value

G. Arkansas County, Arkansas

Mississippi River Valley alluvial aquifer

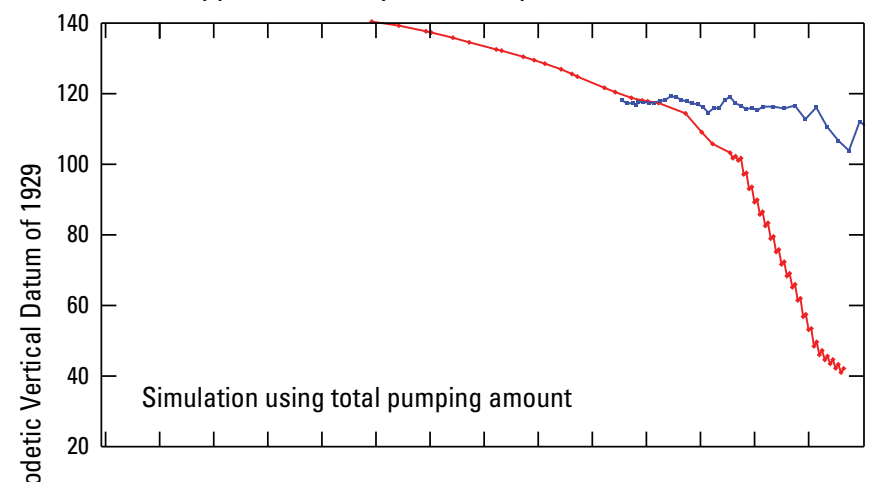

G. Arkansas County, Arkansas

Mississippi River Valley alluvial aquifer

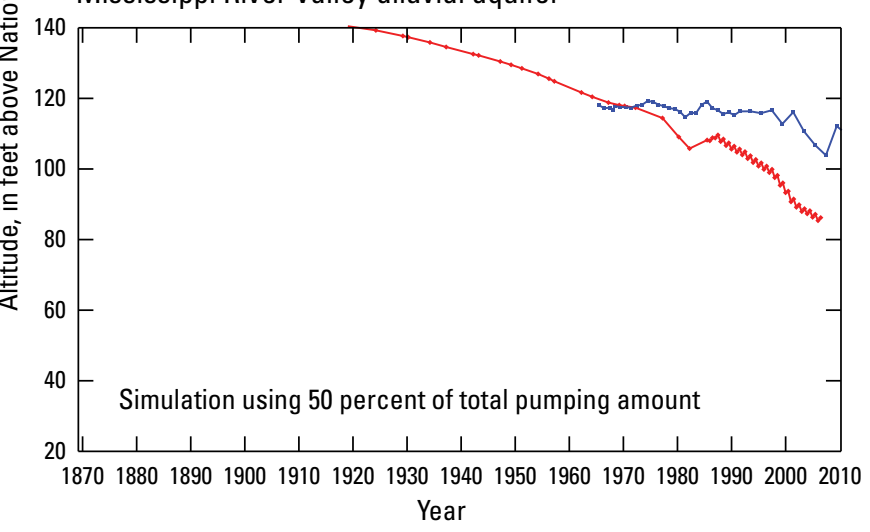

EXPLANATION

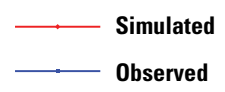

Figure 8. Comparison of hydrographs for simulations using total pumping and a 50-percent reduction in pumping. was $13.76 \mathrm{ft}$ after the 50 -percent reduction in pumping for the alluvial aquifer (compared to a RMSE of $14.14 \mathrm{ft}$ using total reported pumping). Though this improvement is small, it represents the sum total of all alluvial aquifer observations. Many of those observations may not have been affected by the reduction of water use, but the larger improvements in local areas are still reflected (fig. 8).

\section{Scenario Development}

MERAS model version 2.0 may be used to simulate water-level altitudes associated with prolonged pumping to evaluate sustainability of current and projected water-use demands. The following scenarios utilized a steady-state version of the MERAS model that includes average input conditions of streamflow, precipitation (which is converted to net recharge), and the appropriate average pumping condition for the scenario under evaluation. Because of numerical instability within the steady-state scenarios, layer 1 (representing part of the alluvial aquifer) required conversion from a convertible layer to a confined layer in the model configuration. This layer conversion may affect the calculation of transmissivity for part of the alluvial aquifer and is addressed further in "Model Limitations." For each scenario, the leakage of water from selected reaches of the White, Cache, and Arkansas Rivers (fig. 1) into the alluvial aquifer was extracted from the MERAS model for comparison with regard to effects of groundwater pumping on streamflow. For simplicity, each scenario is summarized as

- Scenario 1 - Steady-state simulation of previous optimized pumping;

- Scenario 2 - Steady-state simulation of recent average pumping with reductions for surface-water diversions;

- Scenario 3A-Steady-state simulation of pumping constraints set at 50 percent of the alluvial aquifer predevelopment saturated thickness or $30 \mathrm{ft}$ above the bottom of the alluvial aquifer, whichever was greater; and

- Scenario 3B - Steady-state simulation of pumping constraints used in scenario 3A, with constraints on Sparta aquifer wells in the Grand Prairie area (fig. 1) set to reduce leakage from the overlying and hydraulically connected alluvial aquifer.

Scenario 1 was developed to use pumping values resulting from the optimization of 100 percent of baseline rates (typically 1997 pumping rates) from previous optimization modeling of the alluvial aquifer (Czarnecki and others, 2003a,b) and the Sparta aquifer (McKee and others, 2004). Each of the previous optimization models used individual models of the alluvial and Sparta aquifers and three modeling packages, MODFLOW-96, MODMAN, 
and MINOS (Harbaugh and McDonald, 1996; Greenwald, 1998; Murtaugh and Sanders, 1998). The models also determined the maximum total of surface-water and groundwater pumping from the system while maintaining desirable water levels in the aquifer and in streamflows. In each model, 100 percent of the baseline rates indicated that the optimized result placed an upper limit equal to the baseline pumping rate on the amount each well would be allowed to pump. Optimized pumping totals from the previous optimization models for each county within Arkansas were distributed to alluvial and Sparta aquifer wells in the MERAS model version 2.0. In this way, scenario 1 was used to compare the simulation of water levels and streamflow of the MERAS model version 2.0 to previous models used to estimate sustainable yield with regard to the alluvial aquifer and the Sparta aquifer. Pumping values for counties within the MERAS model version 2.0 that were not included in previous optimization work were assigned average pumping rates from recent years 2000 to 2005 .

Scenario 2 was developed to evaluate the prolonged effects of pumping from the alluvial aquifer at recent pumping rates with reductions for surface-water diversions. The average pumping for each model cell of all wells in the model, including the alluvial aquifer, from 2000 to 2005 was calculated to represent recent pumping amounts. Because the MERAS model version 2.0 incorporates the MODFLOW MNW1 Package (Halford and Hanson, 2002) to simulate pumping wells, the ability to limit pumping based on a drawdown constraint is included in the model simulations. Using drawdown constraints, pumping is reduced (possibly to the point of zero pumping) when the water level near a well reaches a specified altitude within the well bore. MERAS model versions 1.1 and 2.0 used approximately 2 percent of the aquifer thickness to specify the altitude of drawdown constraints on most pumping wells. In scenario 2, drawdown constraints were assigned as the bottom of the alluvial aquifer for all areas used in previous optimization simulations. Additionally, scenario 2 included reductions of groundwater pumping because of surface-water diversion from the Bayou Meto project area (Bayou Meto Water Management District, 2013) and the Grand Prairie Area Demonstration Project (which is within the Grand Prairie area) (U.S. Army Corps of Engineers, 1999). Surface-water diversion for the Bayou Meto project area is expected to meet approximately 73 percent of the total demand. As such, pumping from all alluvial aquifer wells within the Bayou Meto project area was reduced by 73 percent from the average, recent rate. Surface-water diversion for the Grand Prairie Demonstration Project is planned to approximately equal the total amount of pumping in the project area; therefore, pumping from all alluvial aquifer wells within the project area was reduced to zero.

Scenario 3A was designed to evaluate withdrawal limits from the alluvial aquifer by utilizing drawdown constraints imposed in the MNW1 Package equal to an altitude of approximately 50 percent of the predevelopment saturated thickness of the alluvial aquifer (one of the current water-level criteria for an unconfined aquifer as a Critical Groundwater Area (Arkansas Natural Resources Commission, 2012) or $30 \mathrm{ft}$ above the bottom of the alluvial aquifer, whichever was greater.

By using drawdown constraint altitudes representing approximately 50 percent of the predevelopment saturated thickness, scenario $3 \mathrm{~A}$ would be similar to other simulations that estimate sustainable yield from groundwater. However, the drawdown constraints imposed in MNW1 do not limit pumping based on additional constraints on streamflow reduction, and MNW1 does not provide an optimal pumping solution as with the capabilities of a complete optimization model such as the Groundwater Management Process of MODFLOW-2005 (Ahlfeld and others, 2011). Additionally, because drawdown constraints are assigned within the well bore, simulated water levels may vary significantly between the well bore and the adjoining aquifer. Therefore, while scenario $3 \mathrm{~A}$ provides comparative conditions to evaluate sustainable yield based on current pumping rates, the limitations of optimal pumping, drawdown constraints, and conjunctive use from streams apply.

Scenario 3B was designed to include the drawdown constraints in scenario $3 \mathrm{~A}$ and apply these constraints from the alluvial aquifer wells (at an altitude of approximately 50 percent of the predevelopment saturated thickness of the alluvial aquifer) to the Sparta aquifer wells in the Grand Prairie area. The constraints on the Sparta aquifer wells were set to reduce leakage from the overlying and hydraulically connected alluvial aquifer. The limitations described for scenario $3 \mathrm{~A}$ also apply to scenario $3 \mathrm{~B}$. 


\section{Simulations of Sustainable Water- Level Scenarios}

Steady-state simulations using the MERAS model version 2.0 provide insight to the aquifer system response using previously optimized pumping (scenario 1 ), effects of prolonged recent pumping (scenario 2), and effects from reduced pumping based on drawdown constraints (scenario $3 \mathrm{~A})$. While the results of the four scenarios (1-3B) described above are useful in gaining understanding of the groundwater system as a whole, caution should be used in interpreting the results, and especially before making comparisons to results from an optimization-simulation model, such as with the Groundwater Management Process (Ahlfeld and others, 2011) or other similar tools. In general, results of the four scenarios reflect the different pumping intensities and the importance of simulating the multiple aquifers of the system in a single model.

The results of scenario 1 indicate large drawdowns throughout the area of the alluvial aquifer, regardless of the substitution of the optimized pumping values from earlier model simulations (fig. 9a). The simulation of scenario 1 may substantiate the need to simulate the aquifers in the Mississippi embayment as a holistic analysis of the groundwater-flow system. Notice that one area of the alluvial aquifer depletion (water levels that are near or below the bottom of the aquifer) lies on either side of Crowleys Ridge (fig. 9a) and corresponds to an area of water-level decline in the Sparta aquifer (fig. 9b). Positive values represent water levels below the top of the aquifer. This area of the Sparta aquifer (near Crowleys Ridge) was beyond the boundary of the previous optimization simulations, which simulated each aquifer (or part of the aquifer) independently so that pumping from the Sparta aquifer did not interfere with pumping from the alluvial aquifer. Because of this, it is possible that more pumping was allowed from each aquifer during the optimization process than might be expected if the system was simulated as a whole. There may be other explanations for the apparent depletion as well, such as the model construction (hydrogeologic framework), boundary conditions, and aquifer property value differences in the earlier models compared to the MERAS model. However, the simulation of pumping from multiple aquifers appeared to play a partial role and is explored further in scenario 3B. The simulated water level of the Sparta aquifer seems more comparable to the previous optimized version of the aquifer in which most water levels over the area are between 100 and $500 \mathrm{ft}$ above the top of the
Sparta aquifer (fig. 9b). Most other water levels that fall below the top of the Sparta aquifer are within the outcrop-subcrop zone, or a relatively small area within Union County, Ark., which was also present in the previous optimization work.

The results of scenario 2 also indicate large areas of water-level decline below half of the saturated thickness throughout the alluvial aquifer (fig. 10). This result is not vastly different, with respect to water levels well below the 50-percent constraint, from a similar simulation using 1997 pumping rates in a steady-state simulation (see fig. 11a of Czarnecki and others, 2003a), which indicates large areas of depleted aquifer (water levels that are near or below the bottom of the aquifer) in parts of the Grand Prairie and Cache Critical Groundwater Area (fig. 10) (Arkansas Natural Resources Commission, 2013b). Within the Grand Prairie project area, water levels are typically below half of the alluvial aquifer saturated thickness, though simulations show that without the reduction in pumping, much of the area is completely depleted. The simulation indicates aquifer depletion in the northern part of the Bayou Meto project area, even with a 73-percent reduction in pumping from the alluvial aquifer. This, as with scenario 1 , may be caused by pumping from multiple aquifers (as explored further in scenarios $3 \mathrm{~A}$ and 3B). The simulation of declines on the east side of Crowleys Ridge may reflect an extension of the measured declines noted in some wells in the area since the 1970s (Schrader, 2010, fig. 4g), and because the MERAS model contains an additional 10 years of information beyond the 1997 base pumping information used in Czarnecki and others (2003a).

Because the simulation of scenario 2 included drawdown constraints set at the bottom of the alluvial aquifer within MWN1, the potential exists for a difference in the amount of pumping specified for the scenario (desired pumping) and the amount of pumping allowed to occur in the simulation. Essentially, as water levels decline during the simulation, pumping from wells decreases through loss of pump performance. This results in large areas within the alluvial aquifer that provide less than 20 percent of the desired pumping amount (fig. 11). (Note that desired pumping includes reductions resulting from surface-water diversions.) In some areas, water levels continued to decline to the point that the aquifer was depleted, thus pumping wells were removed in those areas from the simulation (fig. 11). As may be expected, the total amount of pumping from the alluvial and Sparta aquifers in the area of previously optimized pumping is greater than that of scenario 1 though still less than the desired average amount (fig. 12). 
$\boldsymbol{A}$

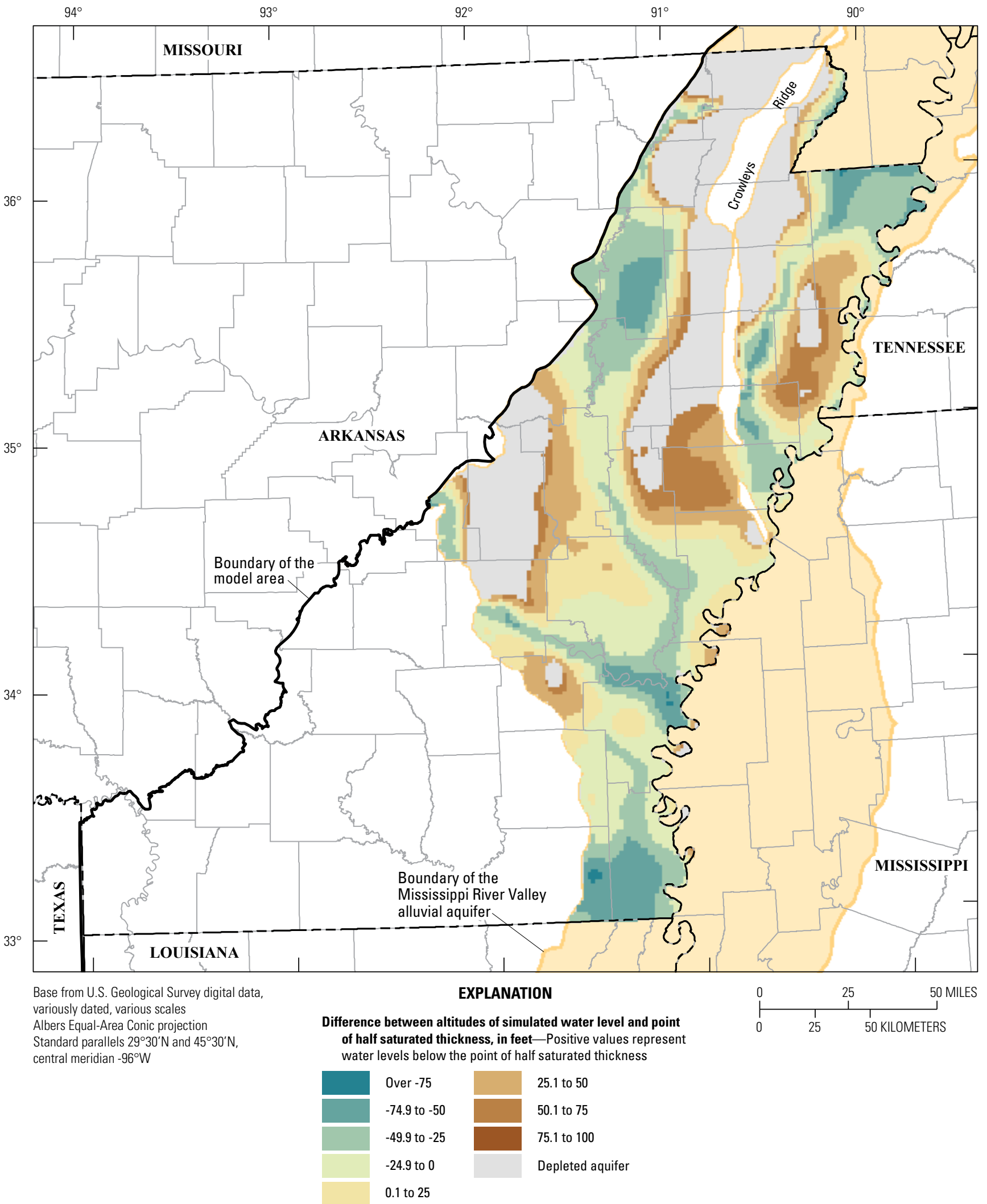

Figure 9. Difference between simulated hydraulic head and the desired drawdown constraint of the $(A)$ alluvial aquifer and $(B)$ Sparta aquifer for scenario 1. 
$\boldsymbol{B}$

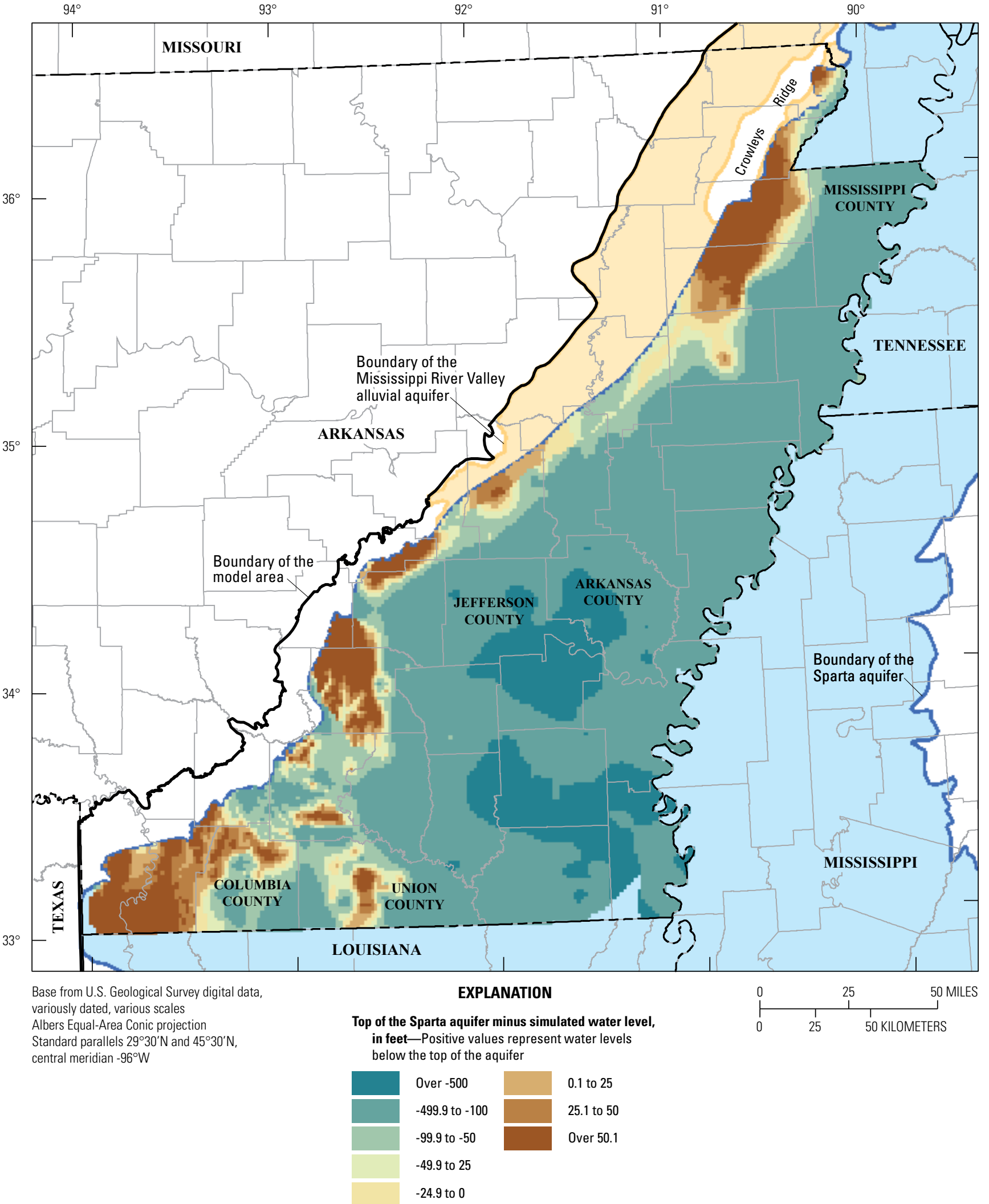

Figure 9. Difference between simulated hydraulic head and the desired drawdown constraint of the $(A)$ alluvial aquifer and $(B)$ Sparta aquifer for scenario 1.-Continued 


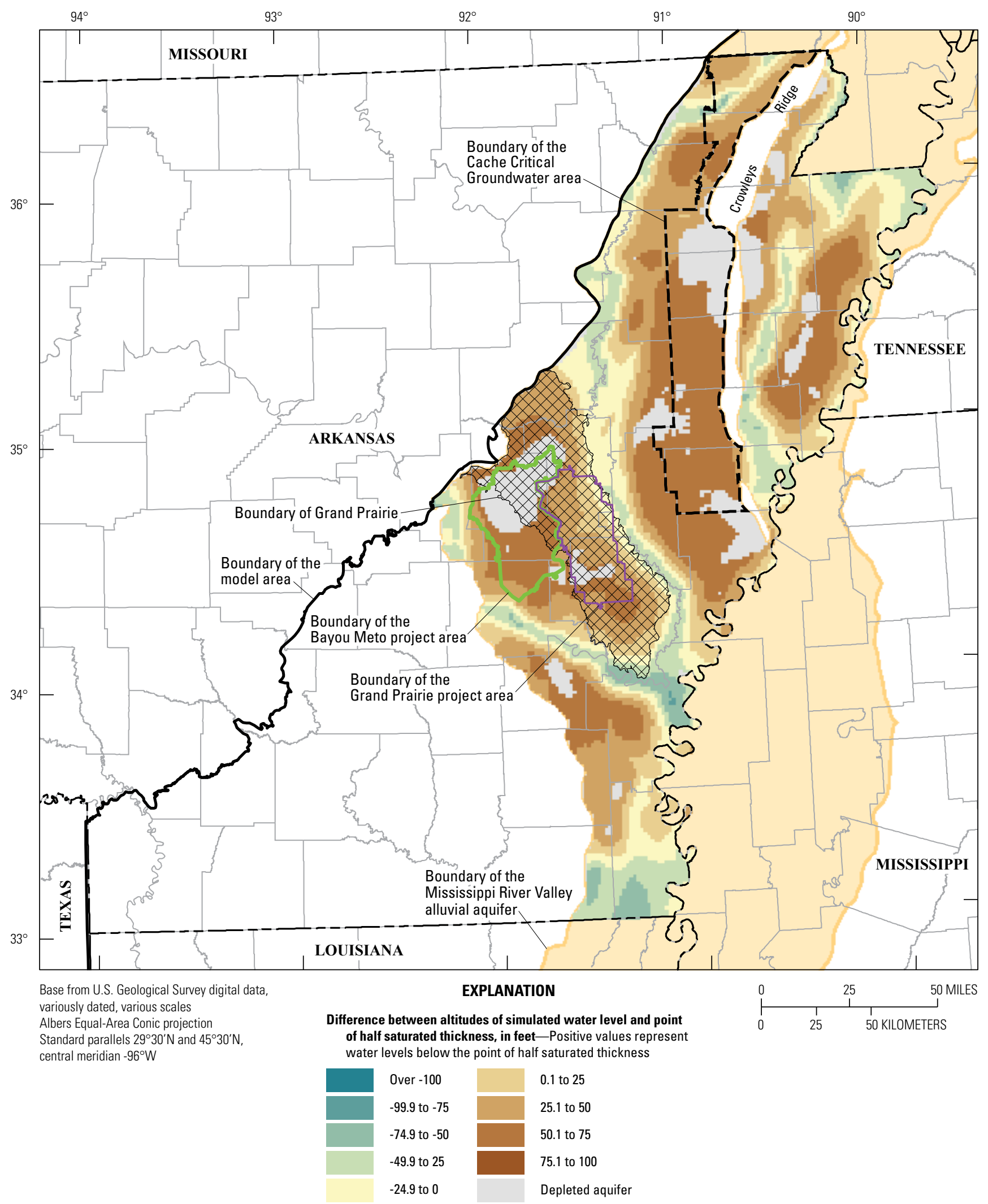

Figure 10. Difference between simulated hydraulic head and half of the saturated thickness of the alluvial aquifer for scenario 2. 


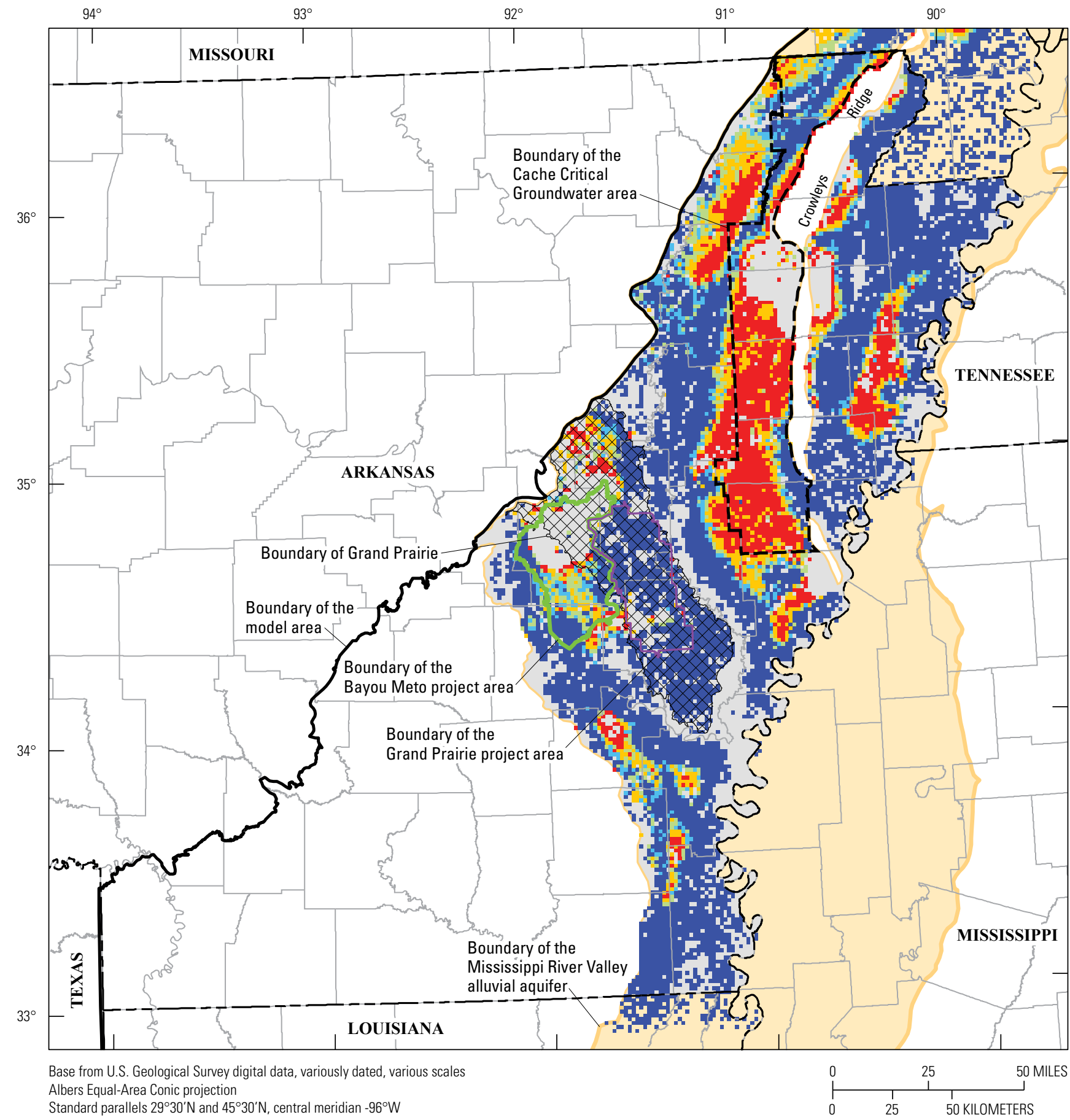

\section{EXPLANATION}

$\begin{aligned} & \text { Percentage of pumping relative to amount of pumping specified } \\
& \text { for the scenario (desired pumping) }\end{aligned}$
\begin{tabular}{|l|l}
0.0 to 20.0 & 60.1 to 80.0 \\
20.1 to 40.0 & 80.1 to 100 \\
40.1 to -60.0 & Area of zero pumping
\end{tabular}

Figure 11. Percentage of desired pumping for scenario 2 . 


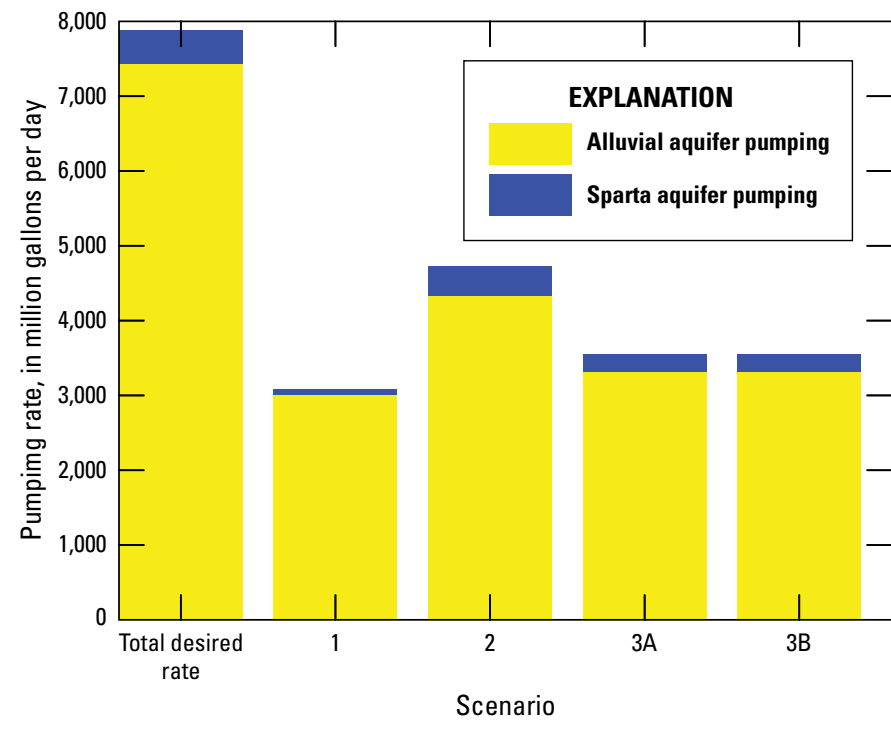

Figure 12. Comparison of pumping rates in the alluvial and Sparta aquifers within the previously optimized areas among each scenario.

The results of scenario $3 \mathrm{~A}$ reveal some effects from the inclusion of multiple aquifers in a single simulation (fig. 13). Initially, scenario $3 \mathrm{~A}$ included drawdown constraints on alluvial aquifer wells based on approximately 50 percent of the predevelopment saturated thickness of the alluvial aquifer or $30 \mathrm{ft}$ above the bottom of the alluvial aquifer, whichever was greater. This configuration resulted in water levels well below the defined drawdown constraint and some areas of depleted aquifer in the Bayou Meto project area (fig. 13a). This scenario reflects the areas where the Sparta aquifer subcrops beneath the alluvial aquifer. In this scenario (3A), the drawdown constraints are at an altitude equal to the potentiometric surface of the alluvial aquifer at 50 percent saturated thickness. If water levels in the Sparta aquifer are allowed below this altitude, leakage from the Sparta aquifer to the alluvial aquifer may occur, further dewatering the aquifer. Because of this effect, the water level of the Sparta aquifer must be maintained at a level equal to or greater than the altitude of 50 percent of the predevelopment saturated thickness of the alluvial aquifer. A fourth simulation (scenario 3B) was configured to include the drawdown constraints in scenario $3 \mathrm{~A}$ and apply these constraints from the alluvial aquifer wells (at an altitude of approximately 50 percent of the predevelopment saturated thickness of the alluvial aquifer) to the Sparta aquifer wells in the Grand Prairie area. These drawdown constraints reduce leakage from the alluvial aquifer to the underlying Sparta aquifer. This configuration did not produce depleted areas within the alluvial aquifer in the Grand Prairie area (fig. 13b). These simulations indicate that even if pumping were limited in the alluvial aquifer, water levels in the alluvial aquifer may continue to decline because of pumping in the underlying Sparta aquifer.

Similar to scenario 2, the drawdown constraints of MNW1 specified in scenario 3B set at half of the saturated thickness of the alluvial aquifer or $30 \mathrm{ft}$ above the bottom of the alluvial aquifer, whichever was greater, allow for a difference in the amount of desired pumping (includes reductions in surface-water diversion areas) and the amount allowed by the drawdown constraints (fig. 14). These results share many similarities to Czarnecki and others (2003a, fig. 8) that simulated large areas of the Grand Prairie and Cache Critical Groundwater areas as unable to sustain pumping under the imposed drawdown constraints. The MERAS model version 2.0 reduces pumping in a manner similar to the previous optimization models, as well as additional areas in the northwestern part of the alluvial aquifer, and also in an area east of Crowleys Ridge (fig. 14). The area of reduced pumping in the northwestern part of the alluvial aquifer may be the result of less accurate thicknesses of the alluvial aquifer or the absence of flow from underlying units, such as the McNairy-Nacatoch aquifer system (Renken, 1998) that was not represented in any of the MERAS models. As with the results of scenario 2, the area of reduced pumping east of Crowleys Ridge may be the result of additional pumping information that was not contained in the earlier optimization work. Though there are additional areas of reduced pumping in the northwestern part of the alluvial aquifer and east of Crowleys Ridge, the total amount of pumping from the alluvial aquifer (within the previously optimized area) is greater than the pumping specified in scenario 1, which corresponds to previously optimized values (fig. 12). The greater amount of pumping allowed by scenarios $3 \mathrm{~A}$ and 3B is likely because of the ability of some wells to pump at the higher average pumping amount, compared to the 1997 pumping rate used as the baseline rate in previous optimizations. Scenario 3B illustrates an estimate of sustained pumping that could be maintained indefinitely because unmet demands on pumping could be obtained through an alternative surface-water supply.

Streamflow leakage from selected reaches of the White and Arkansas Rivers for each scenario indicates the largest amount of leakage to groundwater in scenario 2, which may be expected because of the lack of drawdown constraints. Simulated leakage from the White River (net leakage from the confluence of the Cache River to the Mississippi River) was 290 cubic feet per second $\left(\mathrm{ft}^{3} / \mathrm{s}\right)$ in scenario 1 , increased to $500 \mathrm{ft}^{3} / \mathrm{s}$ in scenario 2, and declined again to 297 and $285 \mathrm{ft}^{3} / \mathrm{s}$ for scenarios $3 \mathrm{~A}$ and 3B, respectively. Simulated leakage from the White River near the end of the calibration period (2006) was approximately $92 \mathrm{ft}^{3} / \mathrm{s}$. Simulated leakage from the Arkansas River (net leakage from the boundary of the model to the confluence of Bayou Meto) was $476 \mathrm{ft}^{3} / \mathrm{s}$ in scenario 1, increased to $523 \mathrm{ft}^{3} / \mathrm{s}$ in scenario 2 , and declined again to 348 and $328 \mathrm{ft}^{3} / \mathrm{s}$ for scenarios $3 \mathrm{~A}$ and $3 \mathrm{~B}$, respectively. Simulated leakage from the Arkansas River near the end of the calibration period (2006) was approximately $178 \mathrm{ft}^{3} / \mathrm{s}$. Simulated leakage from the Cache River did not show appreciable changes in leakage among any scenario, remaining at approximately $5 \mathrm{ft}^{3} / \mathrm{s}$. Simulated leakage from the Cache River near the end of the calibration period (2006) was approximately $3 \mathrm{ft}^{3} / \mathrm{s}$. 


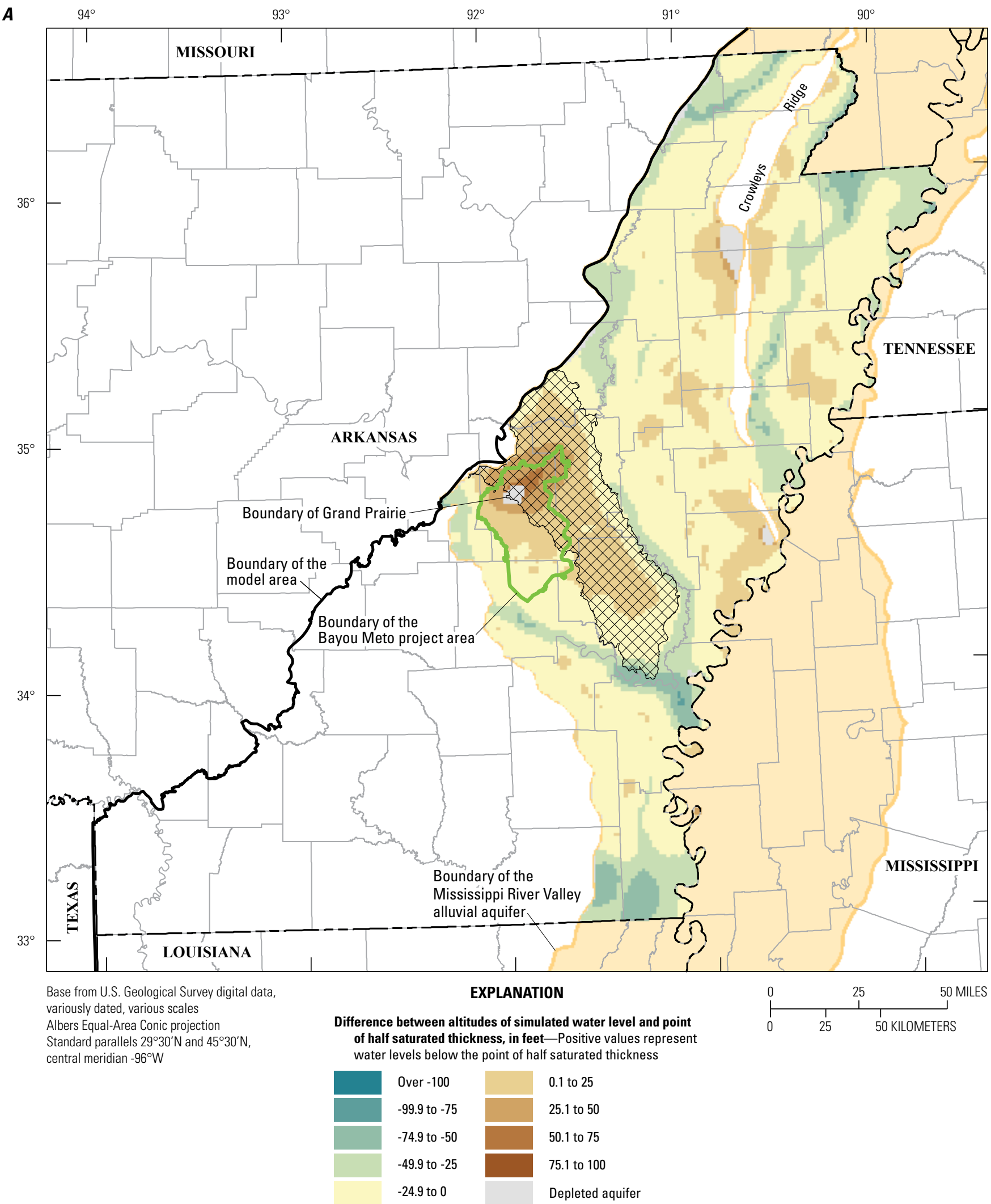

Figure 13. Difference between altitudes of water level and half of the saturated thickness of the $(A)$ alluvial aquifer without drawdown constraints on Sparta aquifer wells and $(B)$ alluvial aquifer with drawdown constraints on Sparta aquifer wells within the Grand Prairie. 
B

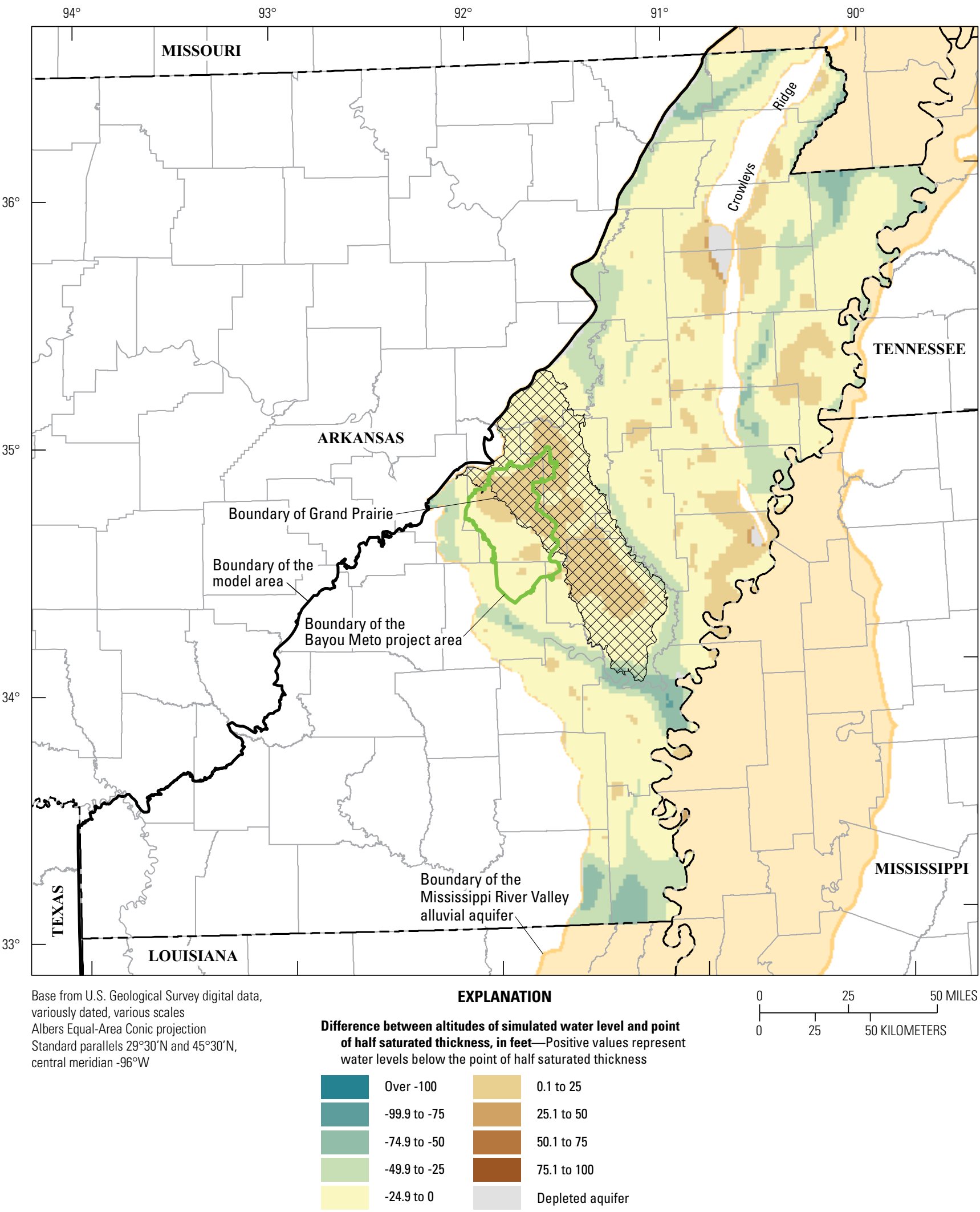

Figure 13. Difference between altitudes of water level and half of the saturated thickness of the $(A)$ alluvial aquifer without drawdown constraints on Sparta aquifer wells and $(B)$ alluvial aquifer with drawdown constraints on Sparta aquifer wells within the Grand Prairie.-Continued 


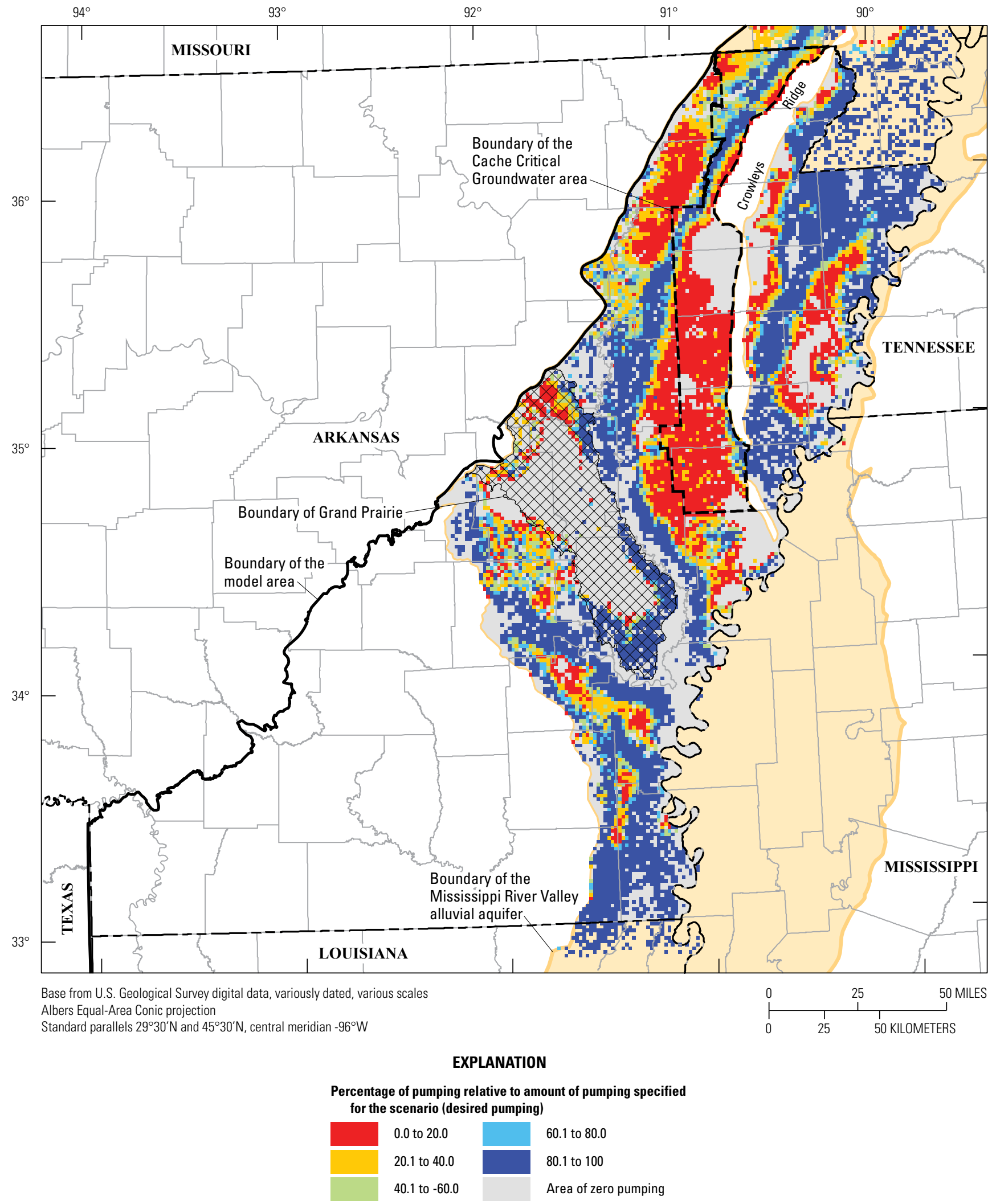

Figure 14. Percentage of desired pumping for scenario 3B. 


\section{Model Limitations}

An understanding of model limitations is essential to effectively use simulation results. Limitations of analysis using the MERAS model are documented in Clark and Hart (2009). A summary of limitations that should be considered when interpreting model results are restated here. Because the model is a simplification of a complex system (for example, local variations in hydraulic conductivity and specific storage are not reflected in the model), some error in simulated water-level altitude is expected. Additionally, results from the scenarios produced using the MERAS model were based on steadystate conditions. Assumptions made for the development of the steady-state model include the continuation of average pumping and average precipitation for long periods of time. Many factors may influence the steady-state assumptions such as climate change, changes in agricultural practices, and growth or decline of population or industry. Thus, the steadystate scenarios are meant to be used as a guide for potential water-level changes if recent average conditions were to continue indefinitely. The additional assumption of confined layers affects the calculation of transmissivity and storage. By doing so, in areas where the water level declines below the confined layer, the transmissivity is not reduced according to the actual saturated thickness. This condition may result in more groundwater flow than is intended.

The goal of the MERAS model was to develop a model capable of suitable accuracy at regional scales. The intent was not to reproduce individual local-scale details, which are typically not possible given the uniform cell size of $1 \mathrm{mi}^{2}$. Although the MERAS model may not represent each local scale detail, it is relevant for a better understanding of the regional flow system.

\section{Summary}

Arkansas continues to be one of the largest users of groundwater in the Nation. As such, long-term planning and management are essential to ensure continued availability of groundwater and surface water for years to come. The Mississippi Embayment Regional Aquifer Study (MERAS) model was developed as a tool to evaluate groundwater availability within the Mississippi embayment, which encompasses much of eastern Arkansas where the majority of groundwater is used. The Arkansas Water Plan is being updated for the first time since 1990 and serves as the State's primary, comprehensive water-resources planning and guidance document. The MERAS model was selected as the best available tool for evaluation of specific water-use pumping scenarios that are currently being considered by the State of Arkansas. The model, developed as part of the U.S. Geological Survey Groundwater Resources Program's assessment of the Nation's groundwater availability, is proving to be invaluable to the State in development of a sustained yield pumping strategy. In an effort to continually improve the MERAS model calibration, and thus the effectiveness of evaluating groundwater availability, the U.S. Geological Survey, in cooperation with the Arkansas Natural Resources Commission, evaluated multiple methods to reduce residual error associated with the Mississippi River Valley alluvial and middle Claiborne (Sparta) aquifers in the MERAS model. Five methods for reducing the residual error were evaluated: (1) explicit simulation of evapotranspiration (ET), (2) upgrade of the Multi-Node Well (MNW) Package, (3) geometry improvement within the Streamflow Routing (SFR) Package, (4) parameter estimation with pilot points, and (5) modification of water-use estimation. For planning purposes of the Arkansas Water Plan, three scenarios were developed to evaluate potential future conditions: (1) simulation of previously optimized pumping values with the Mississippi River Valley alluvial and the middle Claiborne (Sparta) aquifers, (2) simulated prolonged effects of pumping at average recent (2000-2005) rates, and (3) simulation of drawdown constraints on most pumping wells.

Evapotranspiration rates for the simulation period from 1870 to 2007 were estimated from temperature based Potential ET (PET) methods and adjusted to represent ET at the water table. Grids of PET values were developed for each stress period of the model and further adjusted through multipliers similar to those used in the estimation of recharge in earlier versions of the MERAS model to achieve representative values of ET at the water table. The MNW dataset used in the earlier versions of the MERAS model contained well fields in which each well within the same well field was given the same identifier. The MNW dataset also contained duplicate well identifiers, which is not compatible with the MNW2 Package. The duplicate well identifiers were replaced with unique identifiers, or in some cases actual duplicate withdrawals were removed. Wells that were originally placed in multiple layers because of screen placement uncertainty were replaced by withdrawals from a single layer (the lowermost layer representing each hydrogeologic unit) and simulated as a single-node well in MNW2. To improve inputs to the SFR Package, the U.S. Geological Survey obtained measured cross-section data from the U.S. Army Corps of Engineers on the Arkansas and Mississippi Rivers. From these crosssection data, more accurate estimates of mean stream width and depth were calculated. Additional river parameters also were created to represent potential differences in streambed conductance. Many streambed conductances were modified from the original calibrated values to reflect changes in parameterization and geometry. Pilot points were distributed uniformly at a spacing of approximately 5 miles for the alluvial and other surficial aquifers (which included alluvial and terrace deposits beyond the Mississippi River Valley alluvial aquifer) and the Sparta aquifer to represent the aquifer properties of hydraulic conductivity and specific storage. Additional pilot points were generated for the VicksburgJackson confining unit (to represent vertical anisotropy) and recharge multiplier values. During a review of estimated 
water-use values used in the previous MERAS models, some published values in the 5-year water-use reports were found to have corrected values estimated after the initial publication date. Additionally, residuals in select counties such as Columbia, Jefferson, and Union County, Arkansas, indicated potential issues with the estimated water-use values. Upon further comparison with the time-series data, modifications were made to water use values for select years.

The explicit simulation of ET indicated little, if any, improvement of model fit at the expense of much longer simulation time and was not included in further simulations. Numerous attempts to fully utilize the MNW2 Package were unsuccessful in achieving model stability, although modifications made to the water-use dataset remained intact. Final improvements in the residual statistics may be attributed to a single method, or a cumulative effect of all methods attempted. For comparative purposes to the previous MERAS model, the value of root mean square error (RMSE) was computed for each year. The RMSE for all observations in the model is 22.65 feet ( $\mathrm{ft}$ ) over a range in observed hydraulic head of $741.66 \mathrm{ft}$. The RMSE for alluvial observations is $14.14 \mathrm{ft}$ (an improvement of almost $3 \mathrm{ft}$ ) over a range in observed hydraulic head of $297.25 \mathrm{ft}$. The RMSE for the Sparta aquifer is $32.02 \mathrm{ft}$ (an improvement of approximately $3 \mathrm{ft}$ ) over a range in observed hydraulic head of $634.94 \mathrm{ft}$.

Four scenarios were developed to utilize a steady-state version of the MERAS model that includes average input conditions of streamflow, precipitation (which is converted to net recharge), and the appropriate average pumping condition for the scenario under evaluation. Scenario 1 was developed to use pumping values resulting from the optimization of 100 percent of baseline rates (typically 1997 pumping rates) from previous optimization modeling of the alluvial aquifer and the Sparta aquifer. Scenario 2 was developed to evaluate the prolonged effects of pumping from the alluvial aquifer at recent pumping rates. Scenarios $3 \mathrm{~A}$ and $3 \mathrm{~B}$ were designed to evaluate withdrawal limits from the alluvial aquifer by utilizing drawdown constraints equal to an altitude of approximately 50 percent of the predevelopment saturated thickness of the alluvial aquifer or $30 \mathrm{ft}$ above the bottom of the alluvial aquifer, whichever was greater. The results of scenario 1 indicate large drawdowns throughout the area of the alluvial aquifer, regardless of the substitution of the optimized pumping values from earlier model simulations. In previous optimization simulations, each aquifer, or part of the aquifer, was simulated independently so that pumping from the Sparta aquifer did not interfere with pumping from the alluvial aquifer. Because of this, it is possible that more pumping was allowed from each aquifer than might be expected if the system was simulated as a whole. The results of scenario 2 also indicate large areas of water-level decline below half of the saturated thickness, throughout the alluvial aquifer. The simulation of declines in some areas may indicate the continued declines noted in some wells in the area since the 1970s, and occur partially because the MERAS model contains an additional 10 years of information beyond the 1997 base pumping information used in previous modeling efforts. The results of scenario $3 \mathrm{~A}$ reveal some effects from the inclusion of multiple aquifers in a single simulation. The initial configuration of scenario $3 \mathrm{~A}$ resulted in water levels well below the defined drawdown constraint and some areas of depleted aquifer in east-central Arkansas. A fourth simulation (scenario 3B) was configured to apply the same drawdown constraints from the alluvial aquifer wells to the Sparta aquifer wells in the depleted area. These drawdown constraints reduce leakage from the alluvial aquifer to the underlying Sparta aquifer. This configuration did not produce depleted areas within the alluvial aquifer in the Grand Prairie area. Scenario $3 \mathrm{~A}$ and $3 \mathrm{~B}$ simulations indicate that even with pumping limited in the alluvial aquifer, water levels in some areas may continue to decline because of pumping in the underlying Sparta aquifer.

\section{References Cited}

Ahlfeld, D.P., Barlow, P.M., and Baker, K.M., 2011, Documentation for the State Variables Package for the Groundwater-Management Process of MODFLOW-2005 (GWM-2005): U.S. Geological Survey Techniques and Methods, book 6, chap. A36, 45 p.

Arkansas Natural Resources Commission, 2012, Designation of the alluvial and Sparta aquifers within Arkansas, Jefferson, and Prairie Counties, and parts of Lonoke, Pulaski, and White Counties as a Critical Ground Water Area: Arkansas Natural Resources Commission, accessed October 17, 2012, at http://anrc.ark.org/news-publications/ commission-orders.

Arkansas Natural Resources Commission, 2013a, Arkansas water plan: Arkansas Natural Resources Commission, accessed February 4, 2013, at http://www.arwaterplan. arkansas.gov/.

Arkansas Natural Resources Commission, 2013b, Arkansas ground-water protection and management report for 2011: Arkansas Natural Resources Commission, accessed April 11, 2013, at http://anrc.ark.org/news-publications/annualreports.

Arkansas Natural Resources Commission, 2013c, Water-use registration: Arkansas Natural Resources Commission, accessed June 26, 2013, at http://anrc.ark.org/divisions/ conservation/water-use-registration.

Bayou Meto Water Management District, 2013, Bayou Meto Water Management Project: Bayou Meto Water Management District, accessed April 10, 2013, at http://www.bayoumetowatermanagementproject.com/ areamap.html. 
Clark, B.R., and Hart, R.M., 2009, The Mississippi

Embayment Regional Aquifer Study (MERAS):

Documentation of a groundwater-flow model constructed to assess water availability in the Mississippi Embayment: U.S. Geological Survey Scientific Investigations Report 2009-5172, 61 p.

Clark, B.R., Hart, R.M., and Gurdak, J.J., 2011, Groundwater availability of the Mississippi embayment: U.S. Geological Survey Professional Paper 1785, 62 p.

Czarnecki, J.B., Clark, B.R., and Reed, T.B., 2003a, Conjunctive-use optimization model of the Mississippi River Valley alluvial aquifer of northeastern Arkansas: U.S. Geological Survey Water-Resources Investigations Report 03-4230, $36 \mathrm{p}$.

Czarnecki, J.B., Clark, B.R., and Stanton, G.P., 2003b, Conjunctive-use optimization model of the Mississippi River Valley alluvial aquifer of southeastern Arkansas: U.S. Geological Survey Water-Resources Investigations Report 03-4233, $32 \mathrm{p}$.

Daly, C., Taylor, G.H., Gibson, W.P., Parzybok, T.W., Johnson, G.L., and Pasteris, P., 2000, High-quality spatial climate data sets for the United States and beyond: Transactions of the American Society of Agricultural Engineers, v. 43, p. 1957-1962.

Doherty, J., 2003, Groundwater model calibration using pilot-points and regularization: Ground Water, v. 41, no. 2, p. 170-177, doi:10.1111/j.1745-6584.2003.tb02580.x.

Doherty, J., 2008, PEST model-independent parameter estimation user manual (5th ed.): Watermark Numerical Computing, accessed January 21, 2012, at http://www. pesthomepage.org/Downloads.php.

Doherty, J., 2011, Groundwater data utilities, part A: Overview: Watermark Numerical Computing, February, 2011, accessed January 21, 2012, at http:/www. pesthomepage.org/Downloads.php.

Fienen, M.N., Muffles, C.T., and Hunt, R.J., 2009, On constraining pilot point calibration with regularization in PEST: Ground Water, v. 47, no. 6, p. 835-844.

Greenwald, R.M., 1998, Documentation and user's guide: MODMAN, An optimization module for MODFLOW version 4.0: Freehold, New Jersey, HSI GeoTrans, 112 p.

Halberg, H.N., 1972, Use of water in Arkansas, 1970: Arkansas Geological Commission Water Resources Summary 7, $15 \mathrm{p}$.

Halberg, H.N., 1977, Use of water in Arkansas, 1975: U.S. Geological Survey Open-File Report 76-791, 28 p.

Halberg, H.N., and Stephens, J.W., 1966, Use of water in Arkansas, 1965: Arkansas Geological Commission Water Resources Summary 5, 12 p.
Halford, K.J., and Hanson, R.T., 2002, User guide for the drawdown-limited, multi-node well (MNW) package for the U.S. Geological Survey's Modular Three-Dimensional Finite-Difference Ground-Water Flow Model, versions MODFLOW-96 and MODFLOW-2000: U.S. Geological Survey Open-File Report 02-293, 33 p.

Hamon, W.R., 1961, Estimating potential evapotranspiration: Proceedings of the American Society of Civil Engineers, v. 87, p. $107-120$.

Harbaugh, A.W., 2005, MODFLOW-2005, The U.S. Geological Survey modular ground-water model-The Ground-Water Flow Process: U.S. Geological Survey Techniques and Methods, book 6, chap. A16, variously paged.

Harbaugh, A.W., and McDonald, M.G., 1996, User's documentation for MODFLOW-96, an update to the U.S. Geological Survey modular finite-difference ground-water flow model: U.S. Geological Survey Open-File Report 96-485, 56 p.

Hart, R.M., Clark, B.R., and Bolyard, S.E., 2008, Digital surfaces and thicknesses of selected hydrogeologic units within the Mississippi Embayment Regional Aquifer Study (MERAS): U.S. Geological Survey Scientific Investigations Report 2008-5098, 33 p.

Holland, T.W., 1987, Use of water in Arkansas, 1985: Arkansas Geological Commission Water Resources Summary Number 16, 27 p.

Holland, T.W., 1993, Use of water in Arkansas, 1990: U.S. Geological Survey Open-File Report 93-48, 1 sheet.

Holland, T.W., 1999, Water use in Arkansas, 1995: U.S. Geological Survey Open-File Report 99-188, 1 sheet.

Holland, T.W., 2004, Estimated water use in Arkansas, 2000: U.S. Geological Survey Scientific Investigations Report 2004-5230, 38 p.

Holland, T.W., 2007, Water use in Arkansas, 2005: U.S. Geological Survey Scientific Investigations Report 20075241,32 p.

Holland, T.W., and Ludwig, A.H., 1981, Use of water in Arkansas, 1980: Arkansas Geological Commission Water Resources Summary 14, 30 p.

Hunt, R.J., Doherty, J., and Tonkin, M.J., 2007, Are models too simple? Arguments for increased parameterization: Ground Water, v. 45, no. 3, p. 254-262.

Konikow, L.F., Hornberger, G.Z., Halford, K.J., and Hanson, R.T., 2009, Revised multi-node well (MNW2) package for MODFLOW ground-water flow model: U.S. Geological Survey Techniques and Methods, book 6, chap. A30, $67 \mathrm{p}$. 
Lovelace, J.K., and Johnson, P.M., 1996, Water use in Louisiana, 1995: State of Louisiana Department of Transportation and Development Water Resources Special Report no. 11, 139 p.

Lu, Jianbiao, Sun, Ge, McNulty, S.G., Amatya, Devendra, 2005, A comparison of six potential evapotranspiration methods for regional use in the Southeastern United States: Journal of American Water Resources Association, v. 41, no. 3 , p. 621-633.

Lurry, D.L., 1987, Pumpage of water in Louisiana, 1985: State of Louisiana Department of Transportation and Development Water Resources Special Report no. 4, 21 p.

Maupin, M.A., and Barber, N.L., 2005, Estimated withdrawals from principal aquifers in the United States, 2000: U.S. Geological Survey Circular 1279, 46 p.

McKee, P.W., Clark, B.R., and Czarnecki, J.B., 2004, Conjunctive-use optimization model and sustainable-yield estimation for the Sparta aquifer of southeastern Arkansas and north-central Louisiana: U.S. Geological Survey WaterResources Investigations Report 03-4231, 36 p.

Murtaugh, B.A., and Sanders, M.A., 1998, MINOS 5.5 user's guide: Systems Optimization Laboratory Technical Report SOL 83-20R, Stanford, California, Stanford University, $150 \mathrm{p}$.

Niswonger, R.G., and Prudic, D.E., 2005, Documentation of the Streamflow-Routing (SFR2) Package to include unsaturated flow beneath streams - A modification to SFR1: U.S. Geological Survey Techniques and Methods, book 6, chap. A13, 48 p.

PRISM Climate Group, 2011, PRISM Climate Group: Accessed May 1, 2011, at www.ocs.orst.edu/prism/.
Renken, R.A., 1998, Ground water atlas of the United States: U.S. Geological Survey Hydrologic Atlas, HA 730-F, variously paged.

Schrader, T.P., 2009, Water levels and selected water-quality conditions in the Sparta-Memphis aquifer (middle Claiborne aquifer) in Arkansas, spring-summer 2007: U.S. Geological Survey Scientific Investigations Report 2009-5207, 50 p., 3 pls.

Schrader, T.P., 2010, Water levels and selected water-quality conditions in the Mississippi River Valley alluvial aquifer in eastern Arkansas, 2008: U.S. Geological Survey Scientific Investigations Report 2010-5140, 71 p., 2 pls.

Stephens, J.W., and Halberg, H.N., 1961, Use of water in Arkansas, 1960: Arkansas Geological Commission Water Resources Special Report Series 294, 56 p.

Tikhonov, A.N., 1963, Solution of incorrectly formulated problems and the regularization method: Soviet Mathematics, Doklady, v. 4, p. 1035-1038.

Tonkin, M.J., and Doherty, J., 2005, A hybrid regularized inversion methodology for highly parameterized environmental models: Water Resources Research, v. 41, no. 10 , p. 1-16.

U.S. Army Corps of Engineers, 1999, Eastern Arkansas Region Comprehensive Study: Grand Prairie Region and Bayou Meto Basin, Arkansas Project, Grand Prairie Demonstration Project, General Reevaluation Report, accessed January 2, 2013, at http://w3.mvm.usace.army.mil/ grandprairie/maps/pdf/Earcsv02.pdf.

Walter, W.H., 1982, Pumpage of water in Louisiana, 1980: State of Louisiana Department of Transportation and Development Special Report no. 3, 21 p. 
